\title{
Upper Triassic (Ladinian?-Carnian) reef biota from the Sambosan Accretionary Complex, Shikoku, Japan
}

\author{
Camille Peybernes $^{1} \cdot$ Jérôme Chablais $^{2} \cdot$ Rossana Martini $^{1}$
}

Received: 27 March 2015 / Accepted: 22 July 2015 / Published online: 25 August 2015

(C) Springer-Verlag Berlin Heidelberg 2015

\begin{abstract}
The Middle and Late Triassic was a time of important reef development. This evolution, which is primarily documented in the Tethys realm, comprised several phases from the Anisian to the Rhaetian. To help elucidate the less constrained reef evolution in the Panthalassa domain, samples of reef limestone were collected from several localities along the Sambosan Accretionary Complex in Shikoku Island, southwest Japan. In this paper, we report a well-preserved and comprehensive reef biota, including several taxonomic groups, such as scleractinian corals, calcified sponges, calcareous algae, foraminifers, and microproblematica. Seventeen species are described for the first time in Japan among the 33 that are identified in this study. The assemblage-based biostratigraphy and index taxa indicate a Ladinian?-Carnian age. This new finding corresponds to an older reef limestone than has been previously identified in the Sambosan Accretionary Complex and may represent the initiation of shallow-water carbonate deposition on western Panthalassa seamounts. This work also provides valuable insights on reef ecosystem biodiversity in the Panthalassa domain during the Middle? to Late Triassic.
\end{abstract}

Camille Peybernes

camille.peybernes@unige.ch

Jérôme Chablais

jerome.chablais@genevapetroleum.com

Rossana Martini

rossana.martini@unige.ch

1 Department of Earth Sciences, University of Geneva, 13 rue des Maraîchers, 1205 Geneva, Switzerland

2 Geneva Petroleum Consultants International, 1211 Geneva, Switzerland
Keywords Upper Triassic - Ladinian · Carnian · Reef · Japan · Calcified sponges · Foraminifers . Microproblematica

\section{Introduction}

After the dramatic End Permian extinction, a recovery and proliferation of reef ecosystems occurred during the Middle and, especially, the Late Triassic. This period was characterized by the rise of reefs that were dominated by coralline sponges and scleractinian corals. Based on compositional differences of the coral and sphinctozoan sponge associations, four taxonomic turning points have been established: Middle Anisian to Early Ladinian, Late Ladinian to Early Carnian, Middle and Late Carnian to Early Norian, and Norian to Rhaetian (Flügel 2002). This evolution is predominantly documented in the Tethys realm. To confirm this evolution of reef ecosystem in the Panthalassa domain, more data are needed.

The Late Ladinian to Early Carnian (formerly called the Ladinian-Cordevolian) corresponds to the first reef optimum of the Upper Triassic (Flügel 2002). According to this author, although they belong to different stages, Ladinian and Carnian reefs share many characteristics (i.e., biotic composition, paleogeographical setting, and reef types), but above all they are chiefly characterized by the abundance of microproblematica (e.g., Tubiphytes) and microbial crusts. In the Panthalassa, Ladinian-Carnian shallowwater bioconstructions are very rare, and their description focuses mainly on corals (Roniewicz and Stanley Jr 1998). To improve our knowledge of Panthalassan reefs, this paper describes and illustrates new Triassic biota from the reef limestone of the Sambosan Accretionary Complex (SAC), in Shikoku Island, southwest Japan. 
Limestone units that outcrop in the SAC represent the remains of atoll-type carbonates that were deposited at the top of seamounts in the Panthalassa during the Late Triassic (Kanmera 1969; Tamura 1990; Onoue and Sano 2007; Chablais et al. 2010b). Previous studies of reef limestone in the SAC have evidenced the presence of a lower-middle Norian reef association at the Kamase locality, Kyushu (Onoue and Stanley 2008), a Norian reef biota at Inaba cave, Shikoku (Chablais et al. 2010c) and some representatives of Carnian biota in a few limestone clasts at Koguchi locality, Kyushu (Senowbari-Daryan et al. 2012). Moreover, numerous paleontological studies have described a single taxonomic group from the reef limestone of the SAC. Corals have been reported from Kyushu (Kanmera 1964; Stanley and Onoue 2015), Shikoku (Kobayashi 1931; Okuda et al. 2005; Stanley and Onoue 2015) and the Kii Peninsula (Yamato Omine Research Group 1976; Okuda and Yamagiwa 1978; Okuda 2006). Other studies have reported the occurrence of algae (Endo and Horiguchi 1967; Mori 1983; Senowbari-Daryan et al. 2012), foraminifers (Kristan-Tollmann 1991; Chablais et al. 2011) and sponges (Chablais et al. 2010c; Senowbari-Daryan et al. 2012). However, Ladinian-Carnian reef biota remain poorly documented in the SAC. The aims of this paper are (1) to document occurrences of new reef biota from Shikoku, (2) to discuss the age of the reef limestone that outcrops in Shikoku, and (3) to compare the Tethyan and Panthalassan Ladinian-Carnian reef ecosystems.

\section{Geological setting}

The Sambosan Accretionary Complex (according to Onoue and Sano 2007) is a narrow belt in southwest Japan. It is distributed from the Ryukyu Islands in the south to the Kanto Mountains in the north (Fig. 1a). The SAC represents the southern marginal portion of the Chichibu belt and is separated from the Shimanto Accretionary Complex to the south by the Butsuzo Tectonic Line (BTL) (Fig. 1a). The SAC is composed of basalts, cherts, mudstones and sandstones, and limestone. The limestone units are devoid of siliciclastic material, and the biotic content indicates an Upper Triassic age. The terrigenous-free limestone is interpreted as atoll-type limestone that was deposited at the top of oceanic seamounts (Kanmera 1969; Tamura 1990; Onoue and Sano 2007; Onoue and Stanley 2008; Chablais et al. 2010b). The Upper Triassic limestone units mostly outcrop either (1) as massive limestone slabs or (2) as limestone clasts that are embedded in a volcaniclastic matrix (VCM) (Fig. 2a, b). The limestone slabs are laterally tens of meters to kilometers in size. The limestone clasts are a few centimeters to a few decimeters in diameter and form a breccia with a volcaniclastic matrix (VCM breccia) and
Fig. 1 a Distribution of the Sambosan Accretionary Complex in Japan, modified after Chablais et al. (2011). b Location of the studied localities in Shikoku Island. c-e Maps showing location of studied outcrops: c Loc. 1 Tsuno, d Loc. 2 Mt. Sambosan, e Loc. 3 Mt. Ishidate and Loc. 4 Konose Kyo

basaltic clasts. The first mode of occurrence resulted from the dismantling of the seamount in the trench and/or in the accretionary wedge during the accretion-subduction processes, whereas the second is usually interpreted as debris flow and debris avalanche deposits on the flank of midoceanic seamount prior to the accretion (Onoue and Sano 2007; Chablais et al. 2010a). The breccia units are often in close vicinity to massive limestone slabs. Interestingly, most of the investigated limestone clasts were found close to the BTL. The Ladinian?-Carnian reef biota presented in this study predominantly occur in limestone clasts of the VCM breccia.

\section{Materials and methods}

The studied material, which was collected at four localities (Loc. 1-Loc. 4) in central and eastern Shikoku (Fig. 1b), comes exclusively from limestone clasts that are part of the VCM breccia. To our knowledge, none of these localities, except the type locality of the Sambosan limestone near Kochi, have previously been studied in detail. Sixty-eight thin-sections were prepared, scanned with a high-resolution film scanner (Nikon CoolScan 4000 ED) and observed in transmitted light with an optical microscope. Large polished slabs $(\max .30 \times 20 \mathrm{~cm})$ were prepared for some of the samples to illustrate the geometries and morphologies of the reefal textures. Cathodoluminescence using a $\mathrm{Cl} 8200$ MK5-optical cathodoluminescence with a cold cathode was used on a few samples to reveal specific sedimentological features that are concealed in transmitted light. We used beam conditions of $15 \mathrm{kV}$ at $50-60 \mathrm{~mA}$ with an unfocused beam of approximately $1 \mathrm{~cm}$. The observation chamber had a residual pressure of 80 mTorr. The samples were not coated. The thin-sections were photographed in a dark room with a digital camera: with a normal exposure for natural light and with a long exposure under cathodoluminescence. The parameters were kept fixed to avoid additional treatment. Neither filters nor standards were used for image calibration.

\section{Facies}

The reef limestone from the four localities can be described as coral-sponge-microproblematica boundstone (Fig. 2c, d). Sphinctozoan sponges, corals, and Tubiphytes form a very 

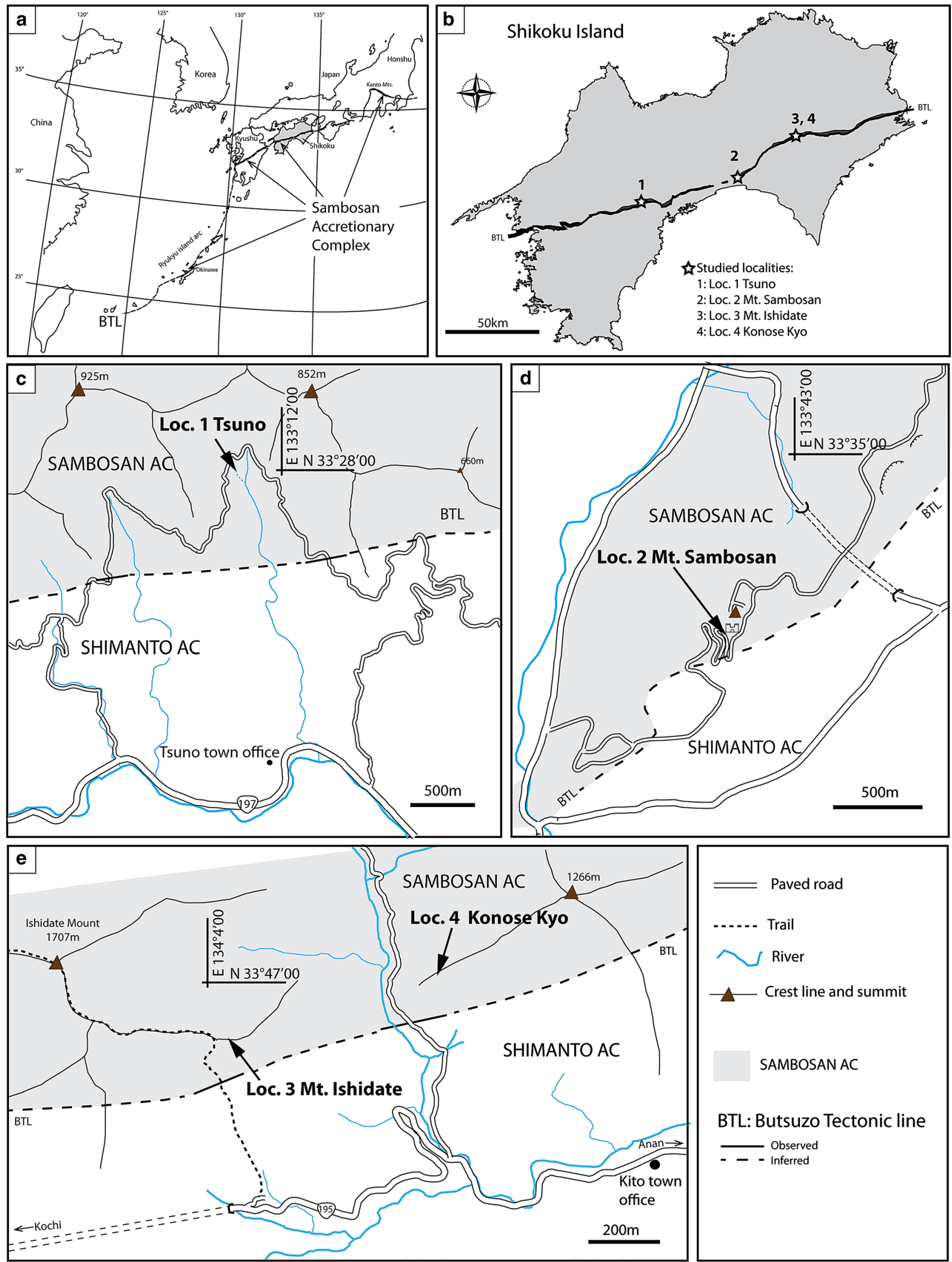

$=$ Paved road

...... Trail

$\circlearrowleft$ River

$\triangle \quad$ Crest line and summit

SAMBOSAN AC

BTL: Butsuzo Tectonic line

- - - Inferred 

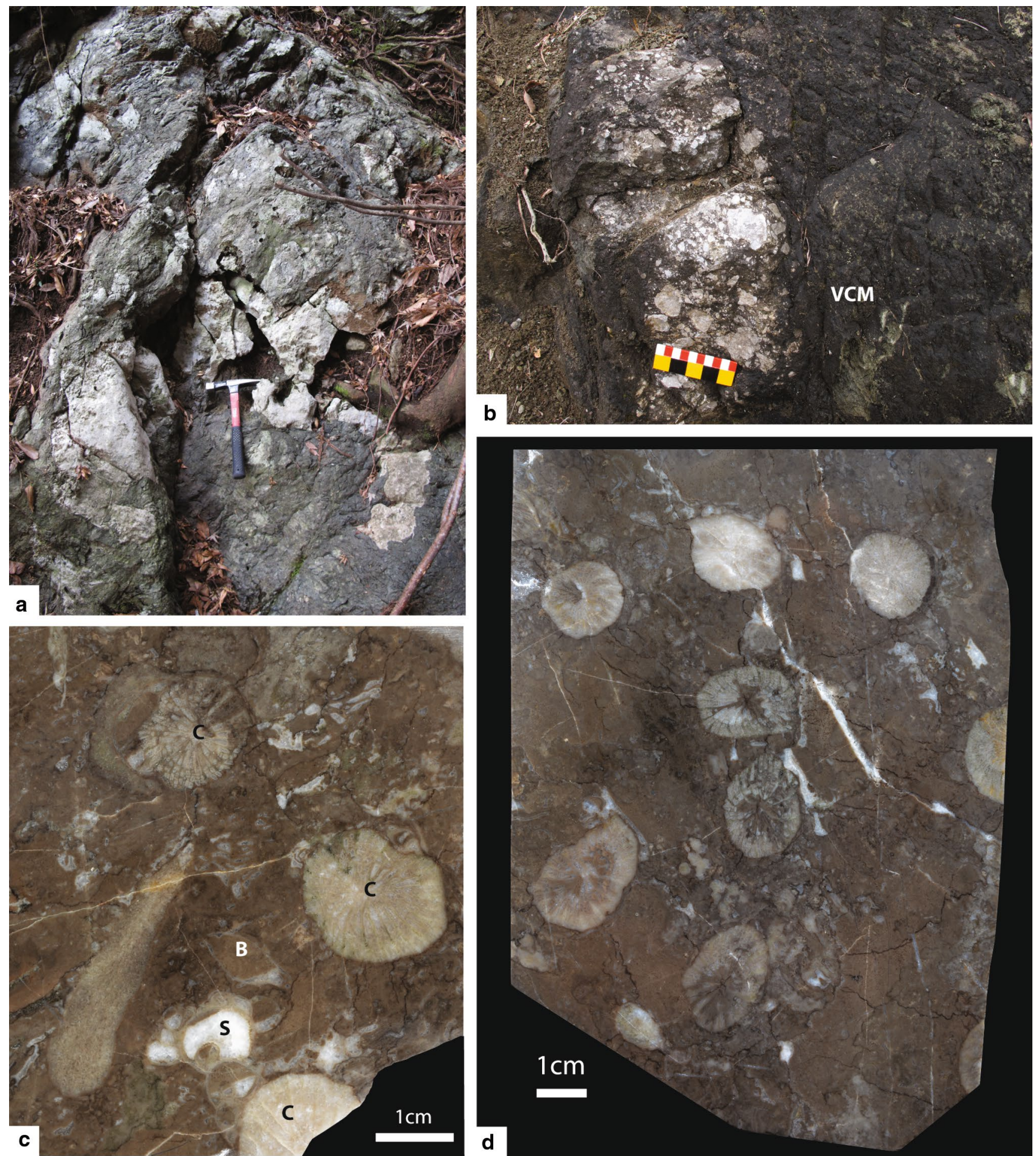

Fig. 2 Outcrops and reef limestone polished slabs. a Reef limestone blocks in VCM Loc. 1 Tsuno. b Limestone clast in VCM breccia Loc. 2 Mt. Sambosan. c Reef limestone polished slab CP127 Loc. 1 Tsuno.

d Reef limestone polished slab CP127 Loc. 1 Tsuno. $B$ Brachiopod, $C$ Scleractinian coral, $S$ Sphinctozoan sponge

loose reef framework. Usually, peloid-microproblematica grainstone-packstone sediment fills the interstices between skeletal elements. Additionally, peloidal and clotted micrite also occupy an important volume of the rock. Most of the

peloids forming the peloidal and clotted micrite are tiny (10-40 $\mu \mathrm{m}$ in diameter) and are possibly of microbial origin (Chafetz 1986; Reid 1987). Encrusting organisms and microbial crusts bind the skeletal elements and the peloidal 
matrix. Voids that are infilled with isopachous cements are locally observed. A general description and the characteristics of the facies for each locality are detailed below.

\section{Loc. 1 Tsuno, Fig. 1c (samples CP120-CP132) 33 ${ }^{\circ}$ $27.870^{\prime} \mathrm{N}-\mathbf{1 3 3}^{\circ} \mathbf{1 1 . 8 6 8}^{\prime} \mathrm{E}$}

The outcrop is situated in a small riverbed, which was dry in March 2012, $2 \mathrm{~km}$ north of the town of Tsuno (Tsuno district, Kochi prefecture) (Fig. 1c). Reefal limestone blocks of tens of centimeters to few meters are embedded in green volcaniclastic and sparry calcite matrix. All of the collected blocks correspond to coral-sponge boundstone with minor amounts of microproblematica and algae. The preservation is good despite minor silicification. The taxonomic diversity is high ( 25 species were determined). The primary framebuilders (mainly corals and sponges) are encrusted by several generations of microbial crust and sessile organisms. There are a few voids with isopachous cements, and peloid-microproblematica grainstone-packstone sediment and peloidal-clotted micrite fill the interstices between the skeletal elements.

\section{Loc. 2 Mount Sambosan, Fig. 1d (samples CP15, CP18, CP 20-25, CP215, JC325G) $33^{\circ} 34.438^{\prime} \mathrm{N}-133^{\circ} 42.741^{\prime} \mathrm{E}$}

This area corresponds to the Sambosan limestone type locality and was first described by Kobayashi (1931) and then investigated by the Yamato Omine Research Group (1981), Okuda et al. (2005), Chablais (2010) and Stanley and Onoue (2015). The studied outcrop is located along the Ryugado Skyline Road, below the castle (Konan district, Kochi prefecture) (Fig. 1d). Reef limestone clasts of few centimeters in diameter occur in a VCM breccia that is in a fault relationship with a large limestone slab. Limestone clasts of other facies (e.g., peloid-echinoderm grainstone and intraclast-bioclast floatstone) are also present in this breccia unit. The reef facies can be described as Tubiphytes-sponges boundstone. Tubiphytes and sponges form a loose framework with abundant interstitial sediment (peloidal and clotted micrite, and peloid microproblematica packstone grainstone). Many large voids are infilled with isopachous cements that occupy the remaining space between the framebuilders. The reef limestone in this locality is relatively well preserved, except for the sponges that are often strongly recrystallized.

\section{Loc. 3 Mount Ishidate, Fig. 1e (samples CP62, CP66) $33^{\circ} 46.800^{\prime}-\mathrm{N} 134^{\circ} 4.019^{\prime} \mathrm{E}$}

Small reef limestone clasts (few centimeters in diameter) have been collected from VCM breccia along the trail that leads to the Mount Ishidate summit (Kito district,
Tokushima prefecture) (Fig. 1e). Clasts are composed of sponge-Tubiphytes-Microproblematica boundstone. Most of the samples are poorly preserved, but some organisms can still be recognized, especially sponges and microproblematica.

\section{Loc. 4 Konose Kyo, Fig. 1e (samples CP40, 41) $33^{\circ}$ $47.009^{\prime} \mathrm{N}-134^{\circ} 4.969^{\prime} \mathrm{E}$}

Reef clasts that are embedded in VCM were found on a mountain crest $200 \mathrm{~m}$ above the road in Konose Kyo (Kito district, Tokushima prefecture) (Fig. 1e). These clasts are a few centimeters in size. All of the clasts that were collected at this locality display reef facies that correspond mainly to sponge-Tubiphytes boundstone, with several large voids that are infilled with isopachous cements. Other outcrops of the SAC in Konose Kyo have been studied by Ishida (1983, 1987), Onoue et al. (2004) and Chablais (2010). The samples are recrystallized but include well-preserved sponges and foraminifera.

\section{Biotic content}

\section{Scleractinian corals}

Scleractinian corals are relatively rare in the SAC although several authors have described Carnian and Norian taxa (Kanmera 1964; Okuda and Yamagiwa 1978; Okuda et al. 2005; Okuda 2006; Onoue and Stanley 2008; Stanley and Onoue 2015). In our samples, corals are represented mainly by phaceloid forms and subordinately by thamnasteroid forms. Corals collected at Loc. 1 Tsuno can be separated into three categories and cautiously assigned to a genus.

Retiophyllia sp. (Fig. 3a)

Material: Several specimens in Loc. 1 Tsuno (samples CP120, 121, 123-127).

Description: Phaceloid colony with corallites of $1.5-2 \mathrm{~cm}$ in diameter. 41-49 septa. No collumella. Depending on the section, few to many densely arranged dissepiments are observed in the corallite periphery (compare Figs. 3a with 8).

Remarks: Four species of genus Retiophyllia are known in the SAC. Retiophyllia cf. R. frechi, which was reported from Kyushu (Stanley and Onoue 2015), closely resemble in size and number of septa (40-48) the species that are described herein. Retiophyllia tosaensis is smaller and has more dissepiments (4-5 per millimeter) and septa. It has been found at Mt. Sambosan (Loc. 2) in VCM breccia together with the Carnian coral Craspedophyllia ramosa (Stanley and Onoue 2015). Retiophyllia eguchii from 

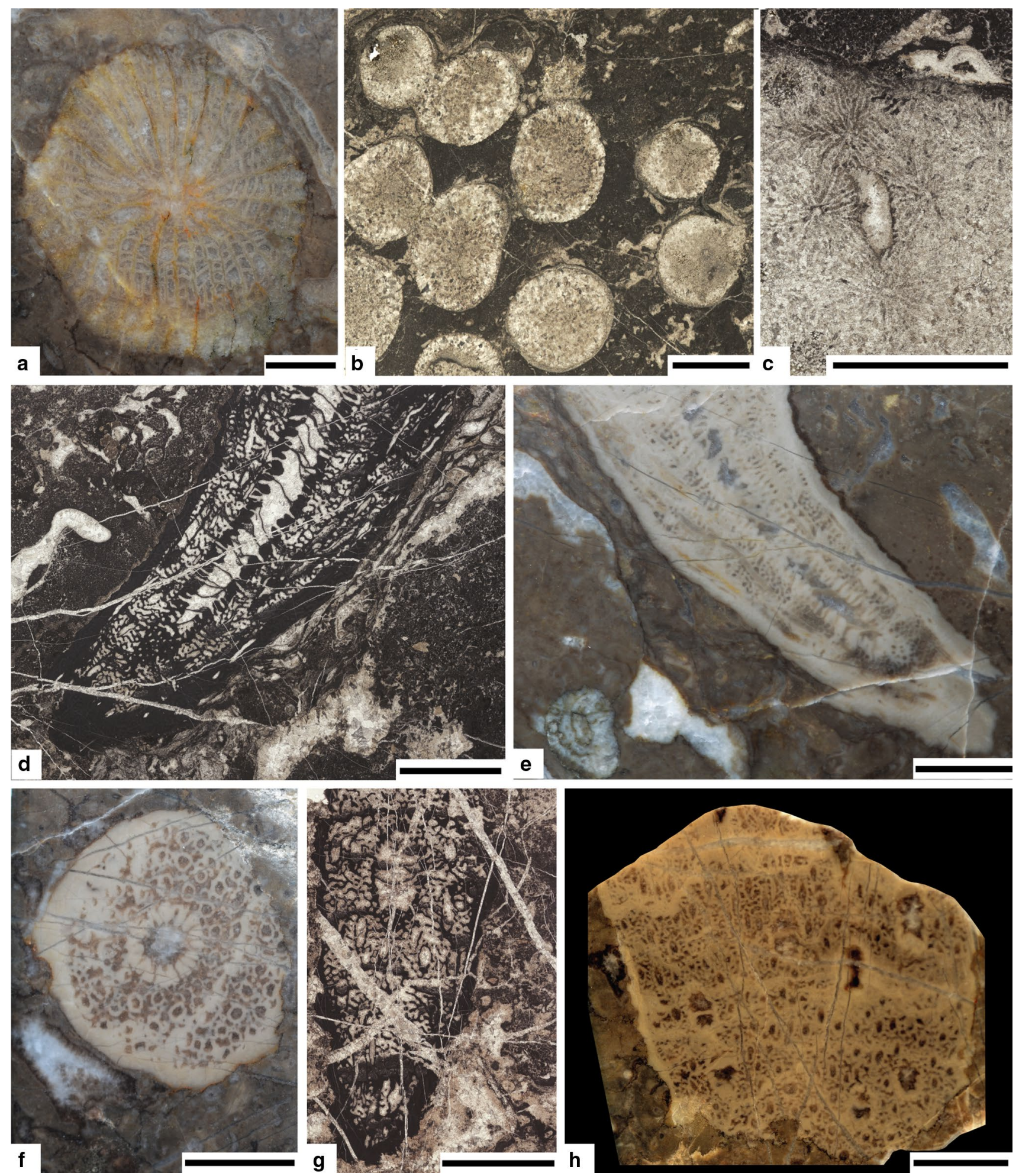

Fig. 3 Scleractinian corals and Zardinia. a Corallite of Retiophyllia sp. with numerous dissepiments CP127. b Coral sp.2 CP127. c Thamnasteriomorpha okudai CP127F. d-f Zardinia perisulcata, d-e Slightly oblique longitudinal sections CP127R, f transversal section
CP131. g Oblique section exhibiting the internally chambered construction CP131B. h Zardinia sp. showing several stems closely clustered together CP131. Scale bars are $5 \mathrm{~mm}$ 
Kyushu (Kanmera 1964) and Retiophyllia wasabiniensis from Kii Peninsula (Okuda and Yamagiwa 1978) also have small-sized corallites and possess more septa and dissepiments. In the material described in this paper, the recrystallization prevented reliable septa cycle analysis and thus determination at the specific level remains questionable. However, considering the size of the corallites and the number of septa, our specimens are closely related to Retiophyllia cf. R. frechi.

Stratigraphic and geographic distribution: Retiophyllia is a common Triassic genus including many species widely distributed in the Tethys and Panthalassa domain.

\section{Scleractinia sp. 1 (Fig. 3b)}

Material: Two specimens in Loc. 1 Tsuno (sample CP127).

Description: Phaceloid colony with closely arranged small corallites $(0.5 \mathrm{~cm}$ in diameter). Corallite sizes and arrangements resemble immature specimens of $R$. tosaensis that were described by Stanley and Onoue (2015). However, this specimen is very recrystallized, which precludes the determination of the species.

\section{Thamnasteriamorpha okudai Stanley and Onoue 2015 (Fig. 3c)}

Material: Two specimens in Loc. 1 Tsuno (sample CP127).

Description: Thamnasterioid colony. Columella is sometimes visible. This specimen is strongly similar to Thamnasteria sp. in Kanmera (1964), Yamato Omine Research Group (1976) and Okuda and Yamagiwa (1978). In their recent revision of corals from the SAC, Stanley and Onoue (2015) attributed specimens that were previously assigned to Thamnasteria sp. to a new species, Thamnasteriamorpha okudai.

Stratigraphic and geographic distribution: Upper Triassic of Japan: Koguchi, Kuyshu (Kanmera 1964; Stanley and Onoue 2015), Wasabidani, Honshu (Yamato Omine Research Group 1976; Okuda and Yamagiwa 1978; Stanley and Onoue 2015) and Tsuno, Shikoku (this study).

\section{Calcareous sponges}

Coralline or hypercalcified sponges include sphinctozoan, inozoan, chaetetids, disjectoporids and spongiomorphids. Their description follows the nomenclature in Senowbari-Daryan and García-Bellido (2002), Finks and Rigby (2004) and Senowbari-Daryan and Rigby (2015). Corallines sponges are frequent in the Sambosan limestone, but recrystallization often precluded an accurate determination. Nevertheless, well-preserved sponges were discovered at Loc. 1 Tsuno and Loc. 4 Konose Kyo.

\section{Sphinctozoans}

Sphinctozoans are a group of sponges with an aragonitic or Mg-calcitic basal skeleton. They represent a highly polyphyletic taxon (Müller-Wille and Reitner 1993).

Zardinia perisulcata Dieci et al. 1968 (Fig. 3d-h)

Material: Five specimens in Loc. 1 Tsuno (samples CP127R, 128, 131B, 132) and two specimens in Loc. 2 Konose Kyo (samples CP41A, 41C).

Description: Conical sponge composed of several chambers, subrectangular in longitudinal section. The spongocoel is axial and is pierced by numerous perforations. The exowall is imperforate and segmentation is not visible from the outside. A reticular filling skeleton exhibiting several irregularly arranged longitudinal tubes is observed.

Remarks: In one sample (Fig. 3h), several stems, each of which is defined by an axial spongocoel, seem to be clustered closely together. This feature would reflect the branching of this specimen. This morphology is close to Zardinia? sp. 2 Senowbari-Daryan and Schäfer (1983; pl. 3, Fig. 6 and pl. 4, Figs. 5, 6, 7).

Stratigraphic and geographic distribution: The genus Zardinia was introduced from the Carnian of the Dolomites (Dieci et al. 1968) and is reported from the Ladinian of the Northern Alps (Wolff 1973), Anisian of Carinthia (Flügel 1986), Carnian of Slovenia (Buser et al. 1982), Carnian of Oman (Bernecker 1996, Senowbari-Daryan et al. 1999), Lower Carnian of Slovenia (Senowbari-Daryan 1981), Wetterstein limestone of Hungary (Flügel et al. 1992), Carnian of Greece (Hydra island, Senowbari-Daryan and Schäfer 1983), Lower Carnian Cipit Boulder Dolomites (SánchezBeristain 2010), Carnian Leckkogel beds (Dullo and Lein 1982). As far as we know, Zardinia is reported here for the first time in Japan.

\section{Cryptocoelia zitteli Steinmann 1882 (Fig. 4a, b)}

Material: One specimen in Loc. 1 Tsuno (sample CP130C), one in Loc. 3 Mt. Ishidate (sample CP66A).

Description: Cryptocoelia zitteli consists of several crescent-shaped chambers that define overlapping flat segments. The chamber walls are porate, and a narrow retrosiphonate spongocoel runs through the skeleton. The chambers are stabilized by wide trabecules, which are also called pillar, which constitute the primary basal skeleton. Characteristically, these trabecules are laminated and are composed of coarse crystalline, and therefore lighter material. In our samples, the lamination of pillars is difficult to see probably due to diagenesis overprint. Vesiculae fill the chambers and constitute a secondary basal skeleton (Müller-Wille and Reitner 1993). 
Remarks: The growth strategy, paleobiology, and taxonomic affinities of this species are discussed in MüllerWille and Reitner (1993). These authors also emphasize the frequent encrustation of this sponge by small Tubiphytes.

Stratigraphic and geographic distribution: Cryptocoelia zitteli is one of the most frequent sponges in the Ladinian and the Carnian reefs of the Tethys (Bernecker 1996). Ladinian of the Northern Calcareous Alps (Wolff 1973), Carnian of Oman (Bernecker 1996), Carnian of Greece (Senowbari-Daryan and Schäfer 1983), Lower Carnian of Slovenia (Senowbari-Daryan 1981), Ladinian-Carnian of Hungary (Flügel et al. 1992), Lower Carnian of the Dolomites. Chablais et al. (2010c) mentioned Cryptocoelia sp. in their study of the Norian reef of Japan. However, Carnian specimens such as $C$. zitteli are here reported for the first time in Carnian of Japan.

\section{?Solenolmia sp. (Fig. 4c)}

Material: One specimen from Loc. 4 Konose Kyo (sample CP41D).

Description: In transversal section of the sponge shows an axial spongocoel and reticular filling skeleton that is similar to $C$. zitteli. The morphology of the chambers is difficult to assess but their arrangement in transversal section suggests a crescent-like shape.

Stratigraphic and geographic distribution: The AnisianCarnian species Solenolmia manon occurs in the Ladinian of the Northern Calcareous Alps (Wolff 1973), AnisianCarnian of the Dolomites (Dieci et al. 1968; Emmerich et al. 2005; Tosti et al. 2014), Lower Carnian of Slovenia (Senowbari-Daryan 1981), Wetterstein limestone of Hungary (Flügel et al. 1992), Carnian Leckkogel beds (Dullo and Lein 1982), Carnian of Oman (Bernecker 1996; Senowbari-Daryan and Bernecker 2009), Carnian of Greece (Senowbari-Daryan and Schäfer 1983) and Carnian of Japan (Senowbari-Daryan et al. 2012). It may also occur in the Norian of Yukon (Senowbari-Daryan and Reid 1987). Other Triassic species of the genus, such as Solenolmia radiata and Solenolmia magna, occur in the Ladinian-Carnian of the Northern Calcareous Alps (Dullo et al. 1987) and Hungary (Velledits et al. 2011).

\section{Celyphia zoldana Ott et al. 1980 (Fig. 4d)}

Material: One specimen at Loc. 1 Tsuno (sample CP127L).

Description: Encrusting sponge composed of upright growing globular chambers. The walls are approximately $150 \mu \mathrm{m}$ thick and are pierced by ostia.

Stratigraphic and geographic distribution: Abundant in Anisian reefs of the Dolomites (Senowbari-Daryan et al. 1993; Emmerich et al. 2005) and Anisian-Ladinian Wetterstein limestone in the Northern Calcareous Alps (Velledits
Fig. 4 Calcareous sponges. a, b Cryptocoelia zitelli a longitudinal oblique section CP130C, b oblique section CP66A. c ?Solenolmia sp., transversal section CP41D. d Celyphia zoldana CP127L. e Celyphia minima; note the ostia (arrows) CP20B. f Stylothalamia dehmi that encrusts Tubiphytes sp. CP22. g, h Uvanella irregularis, illustrating various growth forms CP130C, CP41D. i, j Uvanella? lamellata CP123, CP127D. k Close-up view of Uvanella? lamellata chambers; note the presence of tubes (arrows) CP127D. I, m Transmitted light (I) and cathodoluminescence (m) view of Uvanella? lamellata chambers; note the sharp boundary between the wall and the surrounding clotted micrite CP127I. n ?Murania kazmierc$z a k i$ with typical encrusting pattern and associated microbial crust CP127I. o Close-up view of ?Murania kazmierczaki, note the apical processes (arrows) CP123. p Close-up view of ?Murania kazmierczaki; note the polygonal shape in transversal sections CP124. Scale bars $\mathbf{a}-\mathbf{j}, \mathbf{n} 1 \mathrm{~mm} ; \mathbf{k}, \mathbf{m} 0.5 \mathrm{~mm} \mathrm{o,} \mathrm{p} 0.2 \mathrm{~mm}$

et al. 2011). Other species of the genus Celyphia have been reported from Oman (Senowbari-Daryan and Bernecker 2009) and Oregon (Summit Point, Martindale et al. 2012). It is reported for the first time in Carnian of Japan (this work).

Celyphia? minima Senowbari-Daryan et al. 1993 (Fig. 4e)

Material: Several specimens from Loc. 2 Mt. Sambosan (samples CP20, 23) and Loc. 3 Mt. Ishidate (sample CP66A).

Description: Small sponge that consists of elongated irregular chambers (approximately $1 \mathrm{~mm}$ in diameter). Ostia are sometimes visible in the wall (Fig. 4e, arrows). In our material, the connections between chambers are not clearly defined. The walls are composed of calcite that is darker in comparison with Celyphia zoldana.

Remarks: Senowbari-Daryan et al. (1993) and Emmerich et al. (2005) published several pictures of Celyphia? minima that underline the variable morphology of this sponge.

Stratigraphic and geographic distribution: Abundant in Anisian reefs of the Dolomites (Senowbari-Daryan et al. 1993; Emmerich et al. 2005) and Anisian Ladinian Wetterstein limestone (Velledits et al. 2011). It is reported for the first time in Japan (this work).

\section{Stylothalamia dehmi Ott 1967 (Fig. 4f)}

Material: One specimen at Loc. 2 Mt. Sambosan (sample CP22).

Description: Small specimen composed of several crescent-like chambers with pillars as filling structure. The walls are pierced by numerous pores (diameter 0.06$0.1 \mathrm{ml}$ ). This specimen correspond to the asiphonate form of Stylothalamia dehmi (Senowbari-Daryan and Schäfer 1983).

Remarks: Holotype of Stylothalamia dehmi (Ott 1967) and specimen shown in Senowbari-Daryan et al. (1999) are 

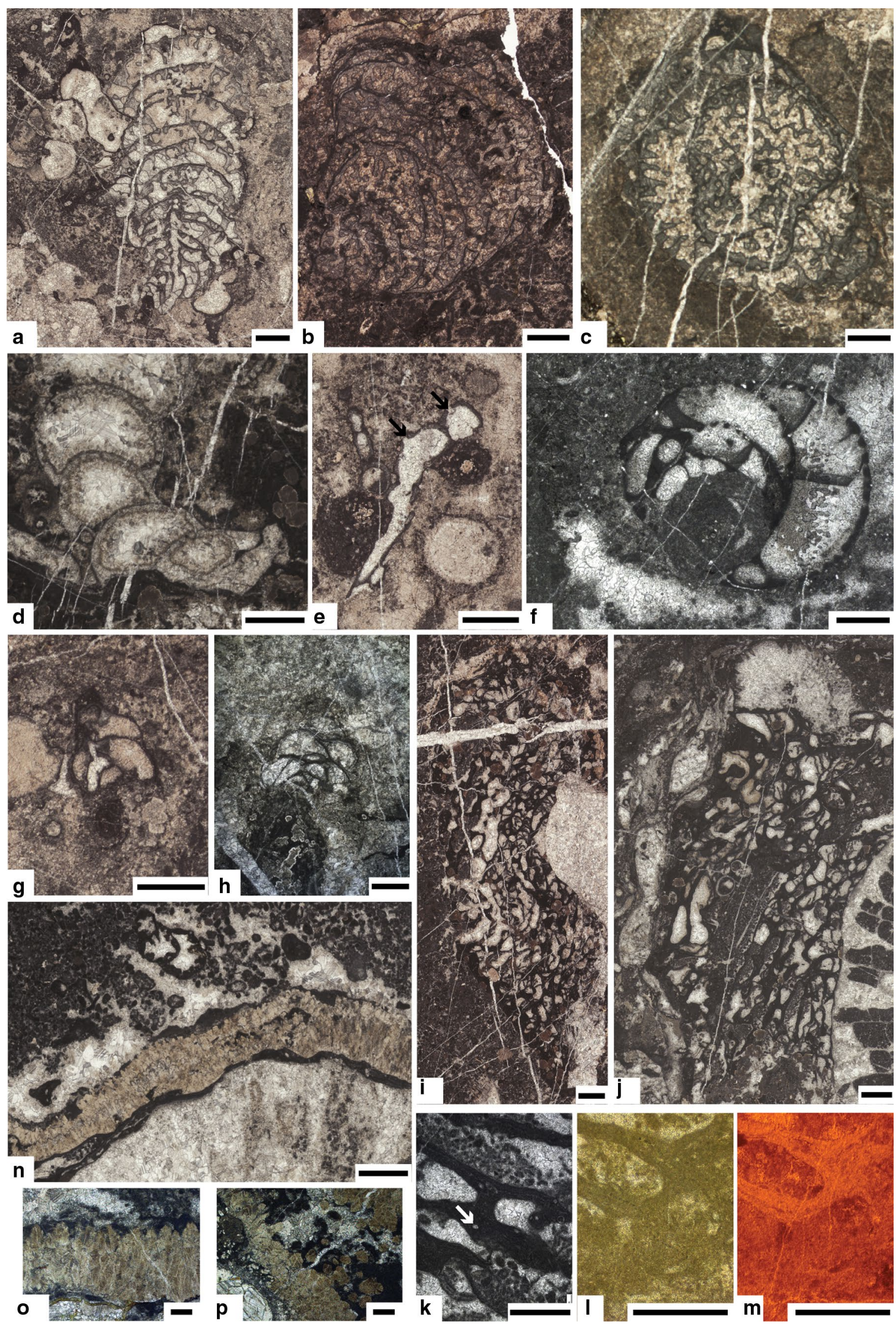
composed of neomorphic calcite. Revision by SenowbariDaryan (1990) demonstrated the original micritic skeleton, as observed in our material.

Stratigraphic and geographic distribution: Ladinian of Northern Calcareous Alps (Ott 1967), Carnian of Slovakia (Jablonsky 1971), Carnian of Slovenia (Senowbari-Daryan 1981), Carnian of Greece (Senowbari-Daryan and Schäfer 1983), Carnian of Oman (Senowbari-Daryan et al. 1999). It is reported for the first time in Japan.

\section{Uvanella irregularis Ott 1967 (Fig. 4g, h)}

Material: Several specimens Loc. 1 Tsuno (sample CP130C), Loc. 2 Mt. Sambosan (sample CP25) and Loc. 4 Konose Kyo (sample CP41D).

Description: Uvanella is a typical encrusting Triassic genus that consists of small, asiphonate chambers (Bernecker 1996). The irregular shape and the size of the segments characterize Uvanella irregularis. Vesiculae and large pores are sometimes present.

Stratigraphic and geographic distribution: Uvanella irregularis occurs in Western Tethys and Oman and are mainly Carnian (Senowbari-Daryan 1981; Dullo and Lein, 1982; Senowbari-Daryan and Schäfer 1983; Boni et al. 1994; Bernecker 1996; Rüffer and Zamparelli 1997). Martindale et al. (2012) reported Uvanella irregularis also from the Lower Norian of Oregon and Chablais et al. (2010c) Uvanella sp. in Norian reef of Japan.

\section{Uvanella? lamellata Senowbari-Daryan 1981(Figs. 4i, j, 8)}

Material: Several specimens in Tsuno (sample CP127).

Description: Encrusting aggregate of irregular rounded asiphonate chambers. The wall consists of more or less laminated micrite and sometimes includes irregularly arranged tubes. Micritic filaments, which obviously come from the wall, are sometime present in the chambers. Important variations in chamber size and wall thickness are observed in the same specimen.

Many bubble-like structures with micritic and, more or less laminated walls, have been described from several Carnian limestone localities around the world (see the list in Senowbari-Daryan and Bernecker 2009). They are usually referred to as "chambered" microbial crust or as doubtful Uvanella? lamellata. In this paper we use the name Uvanella? lamellata for this type of encrusting organism. Nevertheless, the sponge affinity of these structures remains an open question. In particular, thin micritic filaments that are observed in some of the chambers question the sponge affinity of Uvanella? lamellata. The presence of tubes in the wall of some Uvanella? lamellata specimens are also puzzling features (Fig. 4k). Carniphytes multisiphonatus (formerly called "Tubiphytes" multisiphonatus) presents similar tubes in the micritic cortex but the general morphology is different. Permian Tubiphytes sosioensis SenowbariDaryan and Flügel 1993 (see also Sano and Kanmera 1996) also bear some similarities to Uvanella? lamellata but the chambers are smaller, the walls are thicker, and the outline is less defined. The encrustation pattern is also different. The systematic position of Uvanella? lamellata clearly requires deeper investigation.

The cathodoluminescence analysis revealed the sharp boundary between the wall of Uvanella? lamellata and the surrounding microbial clotted micrite (Fig. 41, m). This feature suggests that Uvanella? lamellata and the surrounding microbial clotted micrite correspond to different calcification processes. Thus, the skeleton building of Uvanella? lamellata differed from microbially induced calcification processes and may have been the result of more biologically controlled mineralization.

Remarks: Senowbari-Daryan and Bernecker (2009) emphasized the abundance of Uvanella? lamellata (or this type of microbial crust) in Ladinian-Carnian reefs as well as their role in the stabilization of the reef frame and the contribution to carbonate production.

Stratigraphic and geographic distribution: Uvanella? lamellata is known from the Lower Carnian of Slovenia (Senowbari-Daryan 1981) and the Carnian of Oman (Bernecker 1996; Senowbari-Daryan and Bernecker 2009). It is reported for the first time in Japan (this work).

\section{Other sponges}

\section{?Murania kazmierczaki Reitner 1992 (Fig. 4n-p)}

Material: Several specimens in Loc. 1 Tsuno (samples CP123-125, 127E, 127F, 127I, 127J, 127Q, 127U).

Description: Murania kazmierczaki is an encrusting sponge with a secondary calcitic skeleton. In thin-section, it appears as thick crusts (hundreds of micrometers) that are composed of numerous, closely arranged columns of clinogonal yellow-orange calcite. The upper surface bears short apical processes (Fig. 4o). Columns are polygonal (irregularly pentagonal to hexagonal) in cross section (Fig. 4p). No spicules were observed. The crust-forming morphology and the exclusive occurrence within the several generations of sessile organisms and microbial crust covering the primary framebuilders allow Murania spp. to be distinguished from the isopachous cements that usually fill reef voids and cavities.

Remarks: In the study of the Cipit Boulders of the Cassian Formation (Dolomites, northern Italy), Sánchez-Beristain and Reitner (2012) emphasized the binding role of Murania kazmierczaki in the Cassian reef. These authors reported that Murania kazmierczaki is mainly present in the Precorynella-Margarosmilia association and sometimes 
also in association with Dendronella articulata. In the first association it occurs as the primary encruster on top of Precorynella (an "inozoan" sponge) and is never found on corals. In our samples, ?Murania kazmierczaki settled mainly on corals and sometimes in association with ?Dendronella articulata.

Stratigraphic and geographic distribution: Murania is a genus present from the Carnian to the Albian (Schlagintweit 2004). Murania kazmierczaki is known only from the Lower Carnian of The Dolomites (Sánchez-Beristain and Reitner 2012). It could be reported for the first time in Japan (this work).

\section{Red algae (Solenoporaceans)}

Solenoporacean algae are common in Upper Triassic reefs. In our material, solenoporacean algae are represented by two recognizable specimens (?Parachatetes sp. and Dendronella articulata) from Loc. 1 Tsuno. Poorly preserved fragments have been found at Loc. 1 Tsuno and Loc. $2 \mathrm{Mt}$. Sambosan. The fragments may belong to Parachaetetes sp. or Solenopora sp. The well-preserved specimens are determined as follows.

\section{?Parachaetetes cf. P. cassianus (Flügel 1961) (Fig. 5a)}

Material: One specimen from Loc. 1 Tsuno (sample CP127Q).

Description: Nodular thallus composed of concentric layers of cell rows. The maximum cell diameter is approximately $100 \mu \mathrm{m}$, and the wall is approximately $30 \mu \mathrm{m}$ in thickness. The distance between the cell layers is $500-1000$ $\mu \mathrm{m}$ in longitudinal section and $150-300 \mu \mathrm{m}$ in cross section. Because of the recrystallization, the shape of the cells is difficult to assess. This specimen strongly resembles Parachaetetes cassianus and its dimensions fit with those compiled in Senowbari-Daryan et al. (2006). However a thickening of the wall, which is normally diagnostic of the genus (Senowbari-Daryan and Link 2005; SenowbariDaryan et al. 2006), is not clearly visible. Alternatively, this specimen may belong to Solenopora triasina.

Stratigraphic and geographic distribution: Solenopora and Parachaetetes are common genera in Upper Triassic reefs. Parachaetetes cassianus occur in Carnian limestone clast at Koguchi locality, Sambosan Accretionary Complex of Kyushu, southwest Japan (Senowbari-Daryan et al. 2012).

Dendronella articulata Moussavian and Senowbari-Daryan 1988 (Fig. 5b, d)

Material: Several poorly preserved specimens in Loc. 1 Tsuno (samples CP127E, 127N, 127Q, 127U).
Description: The material consists of fragments of irregular bush-like branching thalli. Branches are circular in transversal section (diameter range from approximately 100 to $200 \mu \mathrm{m}$ ). Filaments are not visible due to strong recrystallization.

Remarks: Dendronella articulata is found in association with ?Murania kazmierczaki.

Stratigraphic and geographic distribution: Carnian of the Dolomites (northern Italy) (Moussavian and Senowbari-Daryan 1988; Russo et al. 1991; Barattolo et al. 1993; Sánchez-Beristain 2010), Carnian of Oman (SenowbariDaryan and Bernecker 2009). It is reported for the first time in Japan (this work).

\section{Cyanophycean calcimicrobes}

Calcimicrobes are only determined at the genus level in this study because of their high morphological variability and lack of diagnostic features.

\section{Girvanella sp. (Fig. 5c)}

Material: The genus Girvanella is relatively common in Loc. 1 Tsuno (samples CP120, 124, 126-127) and Loc. 2 Mt. Sambosan (sample CP25).

Description: Girvanella is a cyanophycean calcimicrobe that is composed of several loosely associated tube-like cells. They correspond to filamentous unbranched calcified mucilaginous sheath and show affinities with the recent genus Plectonema (Riding 1991). Girvanella occurs either as an encrusting organism on corals and sponges or as isolated clusters of tubes.

Remarks: Girvanella is thought to be an important lime mud producer in the Paleozoic (Pratt 2001). Regarding the abundance of Girvanella in our samples, this statement can probably be enlarged to Upper Triassic reefs even if this calcimicrobe is not always well preserved and is thus not well recognizable. The presence of the cyanobacteria Girvanella, which is assumed to be a photoautotroph (Pratt 2001), suggests a depositional setting within the photic zone for the reef limestone of the SAC.

Stratigraphic and geographic distribution: The related species Girvanella fasciculata Schäfer and Senowbari Daryan (1983) is described from the Carnian of Oman (Senowbari-Daryan and Bernecker 2009) and from the Lower Carnian of the Dolomites (Sánchez-Beristain 2010).

\section{Foraminifers}

Foraminifers are relatively abundant in the Sambosan limestone but preservation of the wall structure is often poor. The determination, taxonomy, and classification are based on Zaninetti (1976) and Loeblich and Tappan (1988) along 

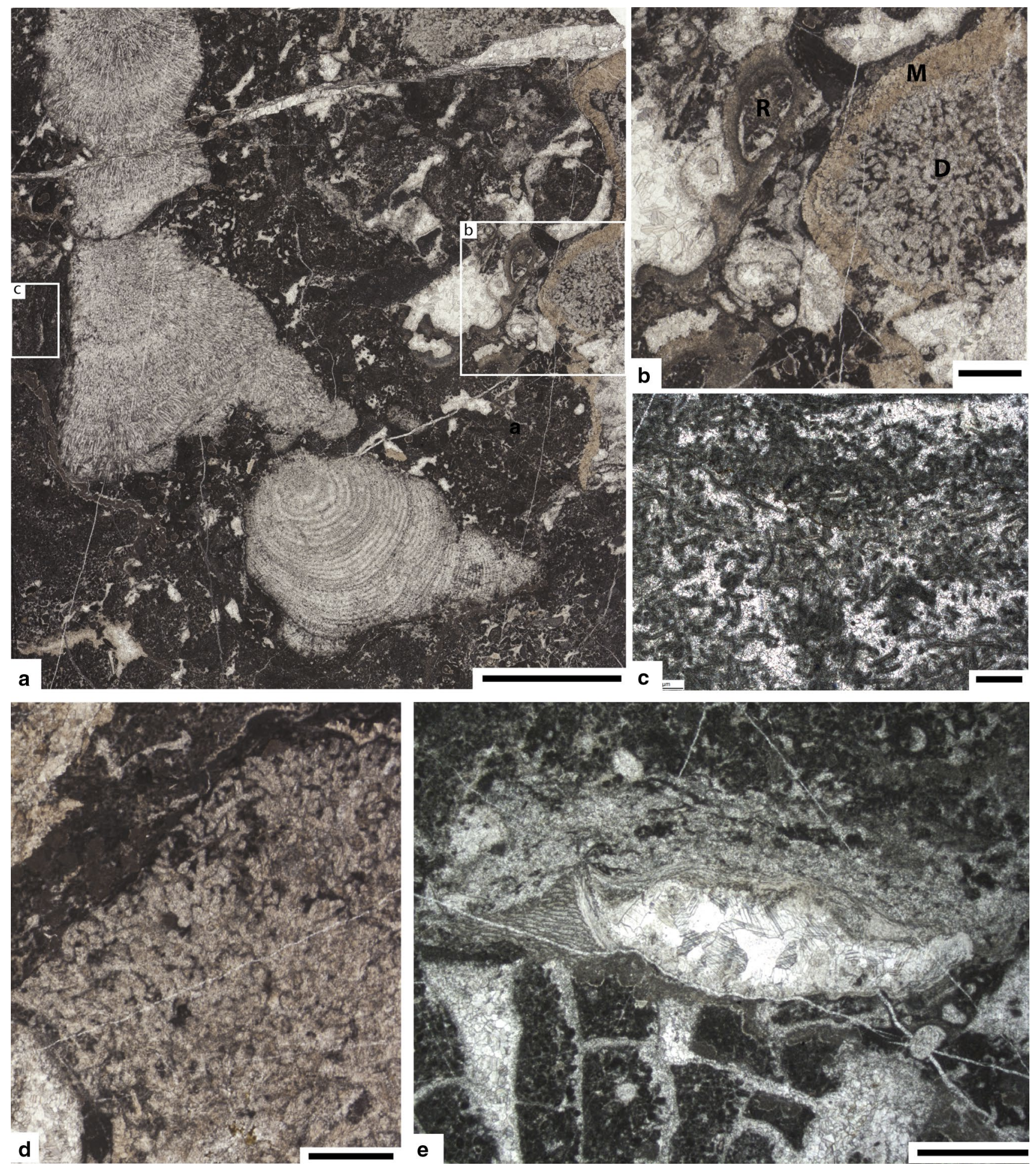

Fig. 5 Algae and calcimicrobes. a Parachaetetes cf. P. cassianus Dendronella articulata CP127U. e Gosaukammerella eomesozoica CP127Q. b Dendronella articulata (D) encrusted by ?Murania CP127D. Scale bars $\mathbf{a}, \mathbf{b}, \mathbf{d}, \mathbf{e} 1 \mathrm{~mm} ; \mathbf{c} 0.2 \mathrm{~mm}$ kazmierczaki (M) and Radiomura cautica (R). c Girvanella sp. d 
with more recent papers. Characteristic (reef and age diagnostic taxa) and well-preserved specimens are presented below. Foraminiferal associations found in the limestone blocks are also reported.

\section{Porcelaneous foraminifers}

\section{Cucurbita infundibuliforme Jablonský 1973 (Fig. 6a-c)}

Material: Six specimens from Loc. 1 Tsuno (sample CP130), three specimens from Loc. 2 Mt. Sambosan (samples CP21, 24B), fourteen from Loc. 4 Konose Kyo (samples CP40, 41).

Description: Cucurbita is a genus of reef-dwelling foraminifer with amphora-like chambers and a thick apertural neck (Gale et al. 2012). Cucurbita-like foraminifer taxonomy has been controversial for a long time (e.g., Zaninetti 1977; Borza and Samuel 1978; Senowbari-Daryan 1983). The review by Gale et al. (2012) led to a much simpler and convincing taxonomic frame that we follow. Based on the observation of thick apertural necks, most of the specimens from the SAC are assigned to Cucurbita infundibuliforme Jablonsky 1973. A few other specimens that exhibit long apertural necks may belong to Cucurbita longicollum Senowbari-Daryan 1983.

Stratigraphic and geographic distribution: Upper Triassic (Carnian) of Oman (Bernecker 1996; SenowbariDaryan and Bernecker 2009), Lower Carnian of Slovenia (Senowbari-Daryan 1981), Carnian of Hungary (Flügel et al. 1992), Carnian of Sicily (Carrillat and Martini 2009), Carnian of Kyushu (Senowbari-Daryan et al. 2012).

\section{Hydrania dulloi Senowbari-Daryan 1983 (Fig. 6d)}

Material: One specimen from Loc. 3 Mount Ishidate (sample CP66A) and eight from Loc. 4 Konose Kyo (sample CP41).

Description: Hydrania dulloi is a typical reef foraminifer that is characterized by an irregularly coiled tube that ends in an elongated amphora-shaped collar. When only the neck is visible, it is difficult to discriminate Cucurbita longicollum and Hydrania dulloi.

Stratigraphic and geographic distribution: Lower Carnian of the Northern Calcareous Alps (Rüffer and Zamparelli 1997), Carnian of Sicily (Carrillat and Martini 2009), Carnian of Greece (Senowbari-Daryan 1983), Carnian of Kyushu (Senowbari-Daryan et al. 2012).

\section{Arenovidalina chialingchiangiensis Ho 1959 (Fig. 6e)}

Material: Several specimens from Loc. 1 Tsuno (samples CP122, 123, 127).
Description: Arenovidalina chialingchiangiensis is a planispiral foraminifer that is characterized by a thick lamellar umbonal region that results in a strongly biconvex test.

Stratigraphic and geographic distribution: Anisian of the Dolomites (Emmerich et al. 2005), Anisian-Ladinian of the Northern Calcareous Alps (Rüffer and Zamparelli 1997), Ladinian-Carnian of Slovenia (Buser et al. 1982), Middle Triassic of China (Ho 1959). It is reported for the first time in Japan (this work).

\section{Microgranular-agglutinated foraminifers}

\section{Paleolituonella meridionalis (Luperto 1965) (Fig. 6f)}

Material: Several specimens from Loc. 1 Tsuno (samples CP127, 128) and Loc. 2 Mt. Sambosan (sample CP24A).

Description: Paleolituonella meridionalis changes from a trochospiral to a linear uniseriate form during ontogeny. Its main characteristics are chamber enlargements during the linear stage and inflated walls between the chambers.

Remarks: Several species of Paleolituonella spp. have been introduced in the literature (P. meridionalis, $P$. min$i m a, P$. reclinata, $P$. angulata). However, they are morphologically similar to each other and should be considered as synonyms (Rettori, pers. comm.). In this work, all of the specimens have been attributed to Paleolituonella meridionalis Luperto 1965.

Stratigraphic and geographic distribution: This species is common (but rarely abundant) in Middle and Upper Triassic shallow-water carbonates of the Tethys.

Piallina tethydis Rettori and Zaninetti 1993 (Fig. 6g) and Piallina bronnimanni Martini et al. 1995 (Fig. 6h)

Material: Piallina spp. are present at Loc. 1 Tsuno (samples CP124, 125) and possibly at Loc. 4 Konose Kyo (sample CP41D).

Description: Piallina is a Carnian genus that is characterized by three stages in their ontogeny (trochoid, triserial, and trochospiral, respectively). Piallina tethydis has subangular chambers, while Piallina bronnimanni is smaller and has more rounded chambers. Accordingly, specimens that are larger than $200 \mu \mathrm{m}$ with triangular chambers are attributed to Piallina tethydis and the smaller one with rounded chambers is attributed to Piallina bronnimanni.

Stratigraphic and geographic distribution: The genus Piallina is known from Carnian of Turkey (Rettori et al. 1993) and Serbia (Martini et al. 1995), and from Ladinian and Carnian of China (Payne et al. 2011). 

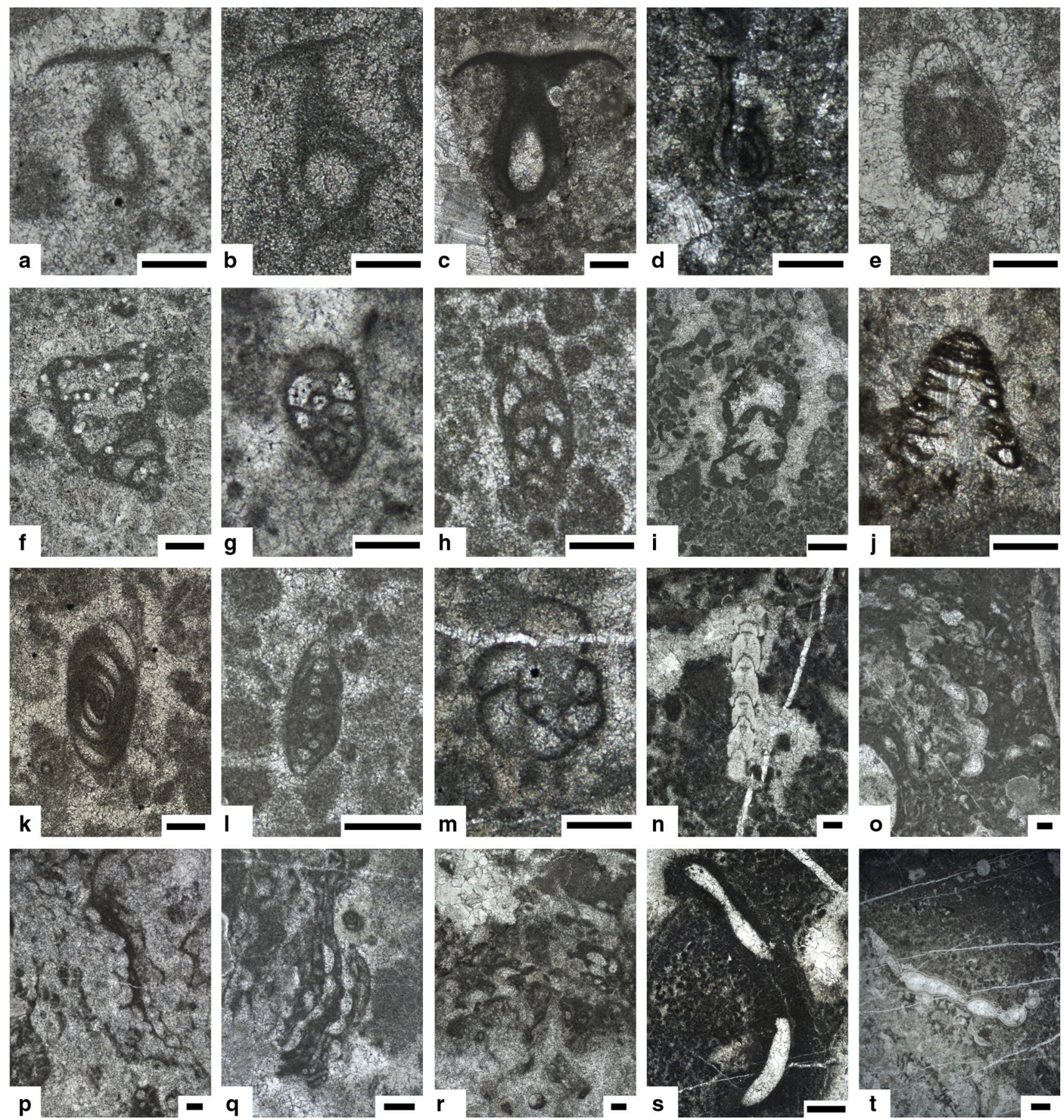

Fig. 6 Foraminifers. a-c Cucurbita infundibuliforme CP21, CP41C, CP130B. d Hydrania dulloi CP41D. e Arenovidalina chialingchiangse CP122. f Paleolituonella meridionalis CP24A. g Piallina bronnimanni CP124. h Piallina tethydis CP125. i Ammobaculites/ Reophax CP127I. j Trocholina cordevolica CP41C. k-I Ophtalminids

Ammobaculites/Reophax (Fig. 6i)

Material: Several specimens from Loc. 1 Tsuno (samples CP121, 123, 127).

Description: Agglutinated trochospiral? to uniserial foraminifers with thick walls and triangular chambers
CP127, CP123. m Endotriada sp. CP121. n Nodosarid CP121 o, p Koskinobullina socialis CP127 K. q, r Nubecularids CP127D. s Terebella sp. CP127D. t Serpulid CP120. Scale bars $0.2 \mathrm{~mm}$ except i, $\mathbf{s}$, t $0.5 \mathrm{~mm}$

are described as Ammobaculites/Reophax. The lack of diagnostic features does not allow a more accurate determination. Agglutinated particles are sometimes well visible.

Remarks: Ammobaculites/Reophax genera are common in interstitial reef sediments at the Tsuno locality. 
Stratigraphic and geographic distribution: Common, long-range (Carboniferous to Holocene) taxon.

\section{Aragonitic foraminifers (Involutinids)}

\section{Trocholina cordevolica Oberhauser 1964 (Fig. 6j)}

Material: One specimen from Loc. 4 Konose Kyo (sample CP41).

Description: The high conical test, which is formed by a trochospirally enrolled, undivided tubular chamber, is characteristic of the genus Trocholina (Rigaud et al. 2013). This form is tentatively attributed to Trocholina cordevolica that is also cited in the literature as Lamelliconus cordevolicus Oberhauser (e.g., Sánchez-Beristain et al. 2013).

Remarks: Involutinids are very rare in reef limestone of the SAC. The specimen of Trocholina cordevolica was found in association with Zardinia perisulcata, C. zitteli, Hydrania dulloi and Cucurbita infundibuliforme.

Stratigraphic and geographic distribution: Trocholina cordevolica is reported from Spain (Pérez-López et al. 2005), Israel (Korngreen and Benjamini 2006), the Dolomites (Di Bari and Laghi 1994; Sánchez-Beristain et al. 2013), and Thailand (Kobayashi et al. 2006). It is reported for the first time in Japan (this work).

\section{Encrusting foraminifers}

?Koskinobullina socialis Cherchi and Schroeder 1979 (Fig. 6o, p)

Material: Several poorly preserved specimens in Loc. 1 Tsuno (sample CP127K).

Description: Small bubble-like cells (80-200 $\mu \mathrm{m}$ long) with light calcitic walls that are more or less arranged in rows. Colonies are composed of several layers that form a crust up to $1 \mathrm{~mm}$. These structures are tentatively attributed to ?Koskinobullina socialis. They differ from nubecularid foraminifers (described below) by the cell arrangement and wall composition.

Remarks: ?Koskinobullina socialis is associated with other encrusting organisms in clotted microbial fabrics.

Stratigraphic and geographic distribution: Carnian to Paleocene (Moussavian and Vecsei 1995), common in Jurassic reefs (Dupraz and Strasser 1999; Ples et al. 2013). In the Upper Triassic it is reported from the Carnian of the Dolomites (Sánchez-Beristain et al. 2013), Lower Norian of Oregon (Martindale et al. 2012), and Rhaetian of the Northern Calcareous Alps (Martindale et al. 2013). It is reported for the first time in Japan (this work).
Nubeculariid foraminifers (Fig. 6q, r)

Material: Several specimens in Loc. 1 Tsuno (sample CP127D).

Description: Small bubble-like cells with dark micritic walls more or less arranged in rows. They differ from ?Koskinobullina socialis by thick micritic walls and a less dense arrangement of chambers.

Stratigraphic and geographic distribution: Nubecularia, one the most common representatives of the nubeculariids, is reported from Norian of the Northern Calcareous Alps (Bernecker 2005), Norian of Oman (Bernecker 2005), Lower Norian of Oregon (Martindale et al. 2012). It is here first reported from Japan.

\section{Foraminiferal association}

The species that are mentioned above occur in association with other foraminifers of minor interest for biostratigraphic and paleoecological purposes. The assemblages commonly contain Endotriada spp. and "Trochammina" sp. together with Ophtalminids, Nodosarids and Duostominids (Fig. 6k-n). Encrusting species such as Planiinvoluta carinata and Tolypammina gregaria are sometimes present.

\section{Microproblematica}

Microproblematica are organisms of unknown biological affinity. They are frequent in the SAC and are often present even in poorly preserved samples. The micritic nature of the skeleton of many of these organisms might explain their relatively good preservation in recrystallized limestone.

\section{Tubiphytes group}

Tubiphytes Maslov 1956 (sometimes called Shamovella, see Senowbari-Daryan 2013), and similar organisms, are one of the most abundant microproblematica group of Late Paleozoic and Mesozoic shallow-water carbonates. The systematic position of these organisms has been the subject of different interpretations. Various groups have been proposed such as sponges, hydrozoans, algae, cyanophycean or foraminifers. Taxonomical and biological affinities of organism that are related to Tubiphytes are discussed in Riding and Guo (1992), Senowbari-Daryan and Flügel (1993), and Senowbari-Daryan (2013), and references therein.

Morphologically, microproblematica that belong to the Tubiphytes group are composed of one or more internal cavities that are surrounded by a more or less dense micritic cortex (or envelop). In this paper, we follow the recent revision of the Triassic Tubiphytes organisms that has been proposed by Senowbari-Daryan (2013). 
Tubiphytes sp. (Fig. 7a-c)

Material: Common microproblematica, present in all investigated localities (Loc. 1 Tsuno, samples CP127, CP129-130; Loc. 2 Mt. Sambosan, samples CP20-25; Loc. 3 Mt. Ishidate CP62, 66A; Loc. 4 Konose kyo, samples CP40-41).

Description: Ramified and unramified specimens with a large elongated tongue-shaped skeleton and an internal cavity composed of a single narrow tube are determined as Tubiphytes spp. The internal cavity is often hidden by diagenetic silicification.

Remarks: On the basis of small morphological differences with respect to the type species Tubiphytes obscurus Maslov 1956, Senowbari-Daryan (2013) defined three new Triassic species of the genus Tubiphytes. However, due to preservation, section orientation, and the morphological plasticity of these organisms, it is not possible to discriminate among the different new species that are introduced by this author in our material.

Stratigraphic and geographic distribution: From Carboniferous to Cretaceous (Jurassic and Cretaceous "Tubiphytes" are called Crescentiella, Senowbari-Daryan et al. 2008) and distributed worldwide.

\section{Plexoramea cerebriformis Mello 1977 (Fig. 7e, f)}

Material: Common microproblematica present in all studied localities (Loc. 1 Tsuno, samples CP124, 127-128, 131; Loc. 2 Mt. Sambosan, samples CP21-22, 24-25; Loc. 3 Mt. Ishidate, samples CP66; Loc. 4 Konose Kyo, samples CP41).

Description: Plexoramea cerebriformis is composed of a thin micritic twig network that surrounds the internal cavity, which is not always visible. The main characteristic is the lack of a defined outer wall, and thus a diffuse transition to the surrounding sediments is observed (SenowbariDaryan 2013). In the literature, Plexoramea cerebriformis is sometime confused with Tubiphytes carinthiacus Flügel. However, specimens that exhibit a clear boundary to the surrounding sediment may belong to Plexoramea cylindrica Senowbari-Daryan 2013 (Fig. 7f).

Stratigraphic and geographic distribution: AnisianLadinian of the Dolomites (Emmerich et al. 2005), Anisian-Ladinian of Hungary (Velledits et al. 2011), Ladinian-Carnian of the Northern Calcareous Alps (Rüffer and Zamparelli 1997), Ladinian-Carnian of Thailand (Fontaine et al. 1988) Carnian of Oman (Senowbari-Daryan et al. 1999), Carnian of Hungary (Flügel et al. 1992), Carnian of the Dolomites (Sánchez-Beristain 2010), Carnian Wetterstein limestone of Slovenia (Bole 2002). One occurrence is reported from the Norian of Sicily (Senowbari-Daryan 1984). It is reported for the first time in Japan (this work).
Plexoramea gracilis (Schäfer and Senowbari-Daryan 1983) (Fig. $7 a, P g$ )

Material: Common in Loc. 2 Mt. Sambosan (sample CP24A), Loc. 3 Mt. Ishidate (sample CP66B) and Loc. 4 Konose Kyo (sample CP41).

Description: Plexoramea gracilis is a thin, branched microproblematica with micritic network in the internal part and was formerly placed in the genus Tubiphytes. Internal cavities are not observed. The diameter is usually approximately $4 \mathrm{~mm}$. Fragments that correspond to this description are tentatively determined as Plexoramea gracilis.

Remarks: This species is limited to the Ladinian-Carnian and was an important debris producer in reefs of the western Tethys (Senowbari-Daryan 2013).

Stratigraphic and geographic distribution: AnisianLadinian of the Dolomites (Emmerich et al. 2005), Anisian-Ladinian of Hungary (Velledits et al. 2011), Ladinian-Carnian of the Northern Calcareous Alps (Rüffer and Zamparelli 1997), Carnian of Oman (Senowbari-Daryan et al. 1999), Carnian of Hungary (Flügel et al. 1992), and Carnian of Kyushu (Senowbari-Daryan et al. 2012).

\section{?Isnella misiki Senowbari-Daryan 2007 (Fig. 7d)}

Material: Several specimens from Loc. 1 Tsuno (sample CP130) and Loc. 2 Mt. Sambosan (samples CP24A, JC325B).

Description: Isnella misiki is composed of a dark micritic envelop that surrounds a small coiled tube. The coiling of the tube defines an internal cavity. Similar organisms are referred to as Labes atramentosa in the Jurassic (Schlaginweit and Gawlick 2009).

Stratigraphic and geographic distribution: Ladinian-Carnian reefs of the Tethys realm (Senowbari-Daryan 2007).

\section{Other Microproblematica}

\section{Baccanella floriformis Pantic 1971 (Fig. 7j)}

Material: Common microproblematica, present in almost all studied localities (Loc. 1 Tsuno, sample CP130; Loc. 2 Mt. Sambosan, samples CP215B; Loc. 4 Konose Kyo, sample CP41D).

Description: Baccanella floriformis is a common microproblematicum in Triassic marine carbonates. It is composed of cauliflower-shaped white calcite aggregates. It occurs as a reef dweller in sediments between framebuilders.

Remarks: The biological affinity of Baccanella floriformis is uncertain. It has been compared to Microcodium in the original description (Pantic 1971). 

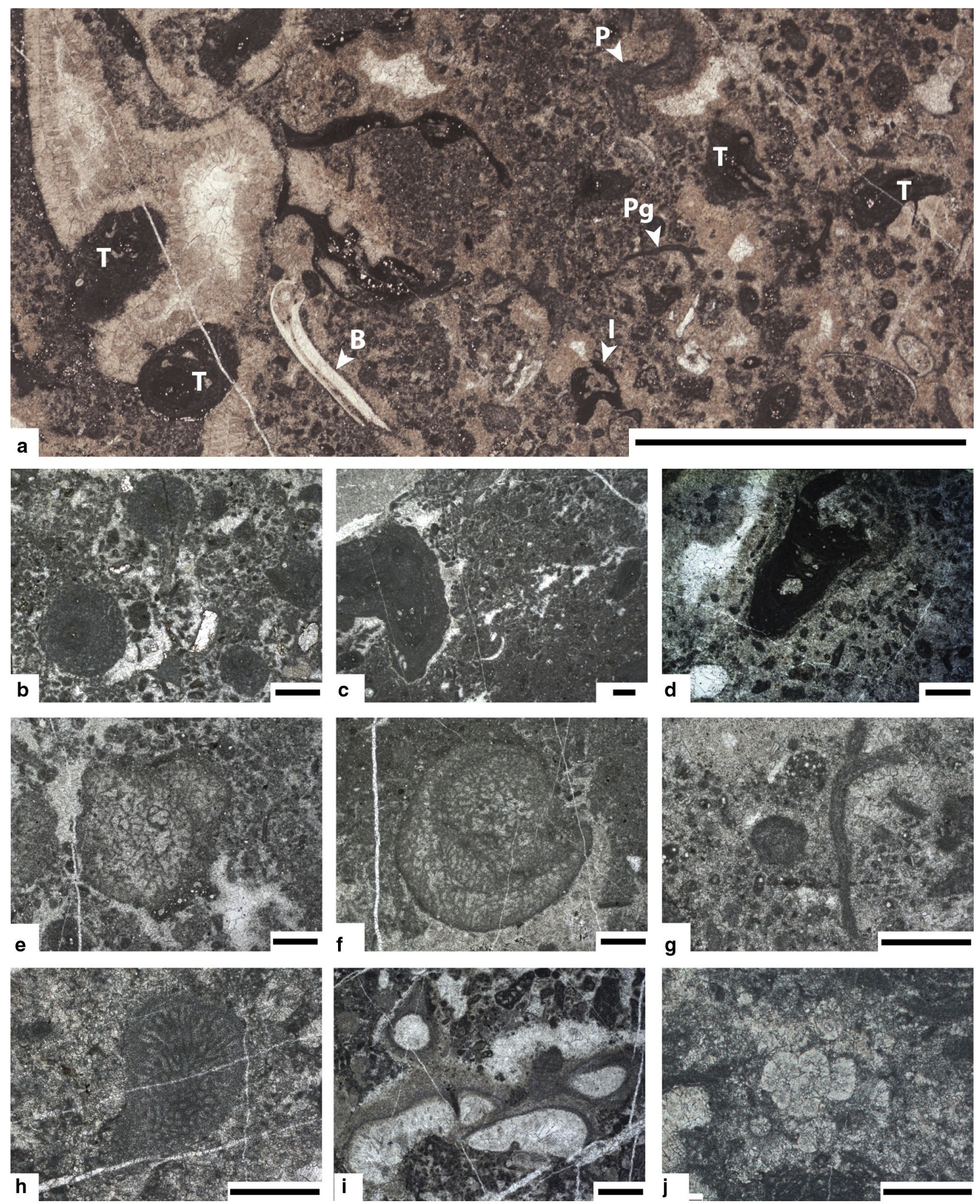

Fig. 7 Microproblematica, brachiopods and worm tubes. a Tubiphytes boundstone (B) brachiopod, (I) ?Isnella misiki, (P) Plexoramea cerebriformis, (Pg) Plexoramea gracilis, (T) Tubiphytes sp. CP24A. b, c Tubiphytes sp. CP62A, CP25. d ?Isnella misiki JC325B. e Plexoramea cerebriformis $\mathrm{CP} 25$. f ?Plexoramea cylindrica $\mathrm{CP} 25 . \mathbf{g}$ Plexoramea gracilis CP24A. h Ladinella porata CP66C. i Radiomura cautica CP123. j Baccanella floriformis CP130C. Scale bars a $5 \mathrm{~mm}$; b-f, h-j $0.5 \mathrm{~mm} ; \mathbf{g} 0.25 \mathrm{~mm}$ 
Stratigraphic and geographic distribution: Common in Middle and Upper Triassic shallow-water carbonates of Tethys.

\section{Ladinella porata Ott 1968 (Fig. 7h)}

Material: Several specimens at Loc. 1 Tsuno (samples CP129, 132) and Loc. 4 Mount Ishidate (sample CP66C).

Description: Ladinella porata is a small microproblematicum that is composed of one or more crescent-like to hemispherical segments that consist of closely associated tubes, which are slightly curved to the periphery. Tubes are usually more visible in the central part of the organism.

Stratigraphic and geographic distribution: Widely distributed in Anisian to Carnian limestone of the Tethys (one doubtful occurrence in the Norian of Sicily is reported in Senowbari-Daryan (1984), reinterpreted here as a Cayeuxialike organism). Upper Anisian of Carinthia (Flügel 1986), Anisian-Ladinian of Hungary (Velledits et al. 2011), AnisianLadinian of The Dolomites (Emmerich et al. 2005; Brandner et al. 1991; Fois 1981), Ladinian-Carnian of the Northern Calcareous Alps (Rüffer and Zamparelli 1997), Ladinian-Carnian of Thailand (Fontaine et al. 1988), Carnian of Slovenia (Senowbari-Daryan 1981)., Carnian of Oman (SenowbariDaryan et al. 1999), Carnian of Hungary (Flügel et al. 1992), Carnian of the Dolomites (Sánchez-Beristain 2010), Carnian Wetterstein limestone of Slovenia (Bole 2002). SenowbariDaryan et al. (2012) also reported occurrence of Ladinella porata in Carnian limestone clast from Kyushu.

\section{Radiomura cautica Senowbari-Daryan and Schäfer 1979} (Fig. 7i)

Material: Common microproblematicum, presents in all studied localities (Loc. 1 Tsuno, samples CP120, 123, 130C, 132; Loc. 2 Mt Sambosan, sample CP22; Loc. 3 Mt Ishidate, samples CP62A, 66B; Loc. 4 Konose Kyo, samples CP41C, 41D).

Description: Radiomura cautica is composed of several irregularly arranged spherical chambers of variable size. The diagnostic feature of this organism is the structure of the wall that usually appears similar to "iron powder in a magnetic field" (Senowbari-Daryan and Bernecker 2009). Various growth forms of Radiomura cautica are described in Wurm (1982). Encrusting or free-living growth forms can be observed.

Remarks: Radiomura cautica have been compared with sphinctozoan sponges (Wurm 1982; Senowbari-Daryan 1984) but the structure of the chamber walls is different (Senowbari-Daryan and Bernecker 2009).

Stratigraphic and geographic distribution: Long-range microproblematicum (Middle Triassic-Upper Jurassic), very common. In Japan it has been reported in the Carnian by Senowbari-Daryan et al. (2012) and in the Norian by Chablais et al. (2010c).

\section{Brachiopods}

Gosaukammerella eomesozoica (Flügel 1972) (Fig. 5e)

Material: Several specimens in Loc. 1 Tsuno (sample CP127D) and Loc. 2 Mt. Sambosan (sample CP215B).

Description: Although it was considered to be a microproblematicum for decades, G. eomesozoica is now interpreted as an encrusting strophomenid brachiopod that inhabited cryptic reef environments (Senowbari-Daryan and Flügel 1996). The specimen in Fig. 5e shows a diagnostic convex pedicle valve with a symmetrically arranged tubular structure that allowed settling on the substrate (here on a coral, but commonly on sponges in the Tethys, Senowbari-Daryan and Flügel 1996), and also shows a flat brachial valve.

Stratigraphic and geographic distribution: Gosaukammerella eomesozoica occurs in the Norian-Rhaetian of the Northern Calcareous Alps (Bernecker 2005), Sicily (Senowbari-Daryan 1984), Oman (Bernecker 1996, 2005), and the Philippines (Kiessling and Flügel 2000), and few Carnian localities in Hungary (Flügel et al. 1992) and Oman (Senowbari-Daryan and Bernecker 2009). As far as we know, Gosaukammerella eomesozoica is here reported for the first time in Japan. This new occurrence in Japan emphasizes the wide distribution of Gosaukammerella eomesozoica (Bernecker 2005).

Apart from Gosaukammerella, diverse other encrusting and free-living brachiopods are present in the Carnian blocks of the SAC. Similar brachiopod shells are sometimes referred to as thecideid brachiopods in the literature (e.g., Sánchez-Beristain 2010).

\section{Polychaetes}

Polychaetes tubes are common components of reef limestone in the SAC. Based on the wall composition, two groups are recognized: agglutinated worm tubes and serpulids.

\section{Agglutinated worm tubes}

Terebella sp. (Fig. 6s)

Material: Several specimens from Loc. 1 Tsuno (samples CP120, 122, 127D, 127GL1, 127M, 130), Loc. 2 Mt. Sambosan (samples CP22, 24B) and Loc. 3 Mt. Ishidate (sample CP66).

Description: Agglutinated worm tubes are isolated or encrusting tubes with irregular dark walls that are composed of agglutinated micrite. Only a few studies on Triassic limestones have assigned agglutinated worm tubes 
to a specific taxon (or even described them). Nevertheless, agglutinated tubes such as Terebella lapilloides Münster 1833 are reported in the Carnian Cipit Boulder of the Cassian formation (Sánchez-Beristain 2010), and they are considered to be common reef dwellers/encrusters in Jurassic reefs (Dupraz 1999; Olivier et al. 2004). Moreover, similar agglutinated worm tubes have been reported from the Upper Triassic of Oman as Porferitubus buseri Senowbari-Daryan 1984 in Bernecker (1996). Porferitubus can be distinguished from Terebella by perforations of the wall. In the Paleozoic, agglutinated worm tubes are often called "Tartharella-like polychaetes worm tubes" but are also referred to as Terebella sp. (Pratt, 1995; Della Porta et al. 2002).

Remarks: Terebella is generally interpreted as a sciaphilic organism and was adapted to low oxygen conditions, for example in cryptic environments between microbialitic columns (Fürsich and Werner 1991; Olivier et al. 2004).

Stratigraphic and geographic distribution: Similar agglutinated worm tubes are common in Phanerozoic carbonate rocks.

\section{Indeterminate serpulids (Fig. 6t)}

Material: Several specimens mainly from Loc. 1 Tsuno (samples CP120, 127U).

Description: Serpulid tubes are characterized by light calcitic walls. Most often serpulids are single tubes that are encrusted on reef builders.

Stratigraphic and geographic distribution: Serpulids are common components of Phanerozoic carbonate rocks.

\section{Discussion}

\section{Correlation of outcrops}

The noticeable homogeneity of the limestone clasts that are found in the four studied localities is testified by the analogous mode of occurrence, microfacies and distribution of reef taxa (Table 1). Indeed, all of the reef limestone clasts were found in similar VCM breccia and can be described as coralsponge-microproblematica boundstone. Furthermore, reef limestone clasts from the different localities have many taxa in common. These observations stress their common origin, which allows this material to be treated as a unique overall biota assemblage despite several local but minor differences.

\section{Biostratigraphy}

The biostratigraphy of Upper Triassic reefs is based on foraminifers, problematica and some reef builders that are associated with reef fauna (i.e., corals and sponges; Bernecker 2005). In this paper, two methods are used to refine the biostratigraphical frame of the Sambosan shallow-water reefal limestone in Shikoku. The first is the occurrence of biostratigraphic markers. The second is the analysis of biotic associations with respect to other coeval faunal assemblages from different localities of the Tethys and Panthalassa oceans. However, a comparison with the eastern Panthalassa is difficult because of the scarcity of Ladinian-Carnian reef fauna in North American terranes and craton. Only rare occurrences are reported currently from the Late Ladinian of Nevada (Roniewicz and Stanley Jr 1998), and the Late Carnian of British Colombia (Zonneveld et al. 2007; Martindale et al. 2010). Thus, our results are mainly compared with Tethyan reef biota. In the next sections, we present the most significant biostratigraphic markers from the Upper Triassic reefs of Shikoku and a comparative analysis of the biotic association.

\section{Biostratigraphic markers}

Several of the species that are mentioned above are considered to be reliable biostratigraphic markers that distinguish the Ladinian-Carnian from the Norian-Rhaetian. Indeed, the compilation of stratigraphic ranges of some of the taxa described above shows that many of the identified taxa are restricted to specific Triassic stages. These include the sponges Zardinia spp. (Anisian to Carnian), C. zitteli (Ladinian to Carnian), the foraminifers Trocholina cordevolica (Late Ladinian to Carnian), Piallina spp. (Ladinian to Carnian) and the microproblematica Ladinella porata (Anisian to Carnian), Plexoramea cerebriformis (Anisian to Carnian) and Plexoramea gracilis (Ladinian-Carnian,). These taxa are widely considered as biostratigraphic markers in the literature. Species belonging to genus Zardinia are exclusively Anisian to Carnian (Senowbari-Daryan 1990; Senowbari-Daryan et al. 1999). Cryptocoelia includes Norian-Rhaetian species but $C$. zitteli is restricted to the Ladinian-Carnian (Müller-Wille and Reitner 1993, Senowbari-Daryan and Bernecker 2009). Trocholina cordevolica is considered as an index fossil for the late Ladinian-Carnian by many authors (Trifonova 1993; Di Bari and Laghi 1994; Pérez-López et al. 2005; Korngreen and Benjamini 2006; Sánchez-Beristain et al. 2013). Plexoramea gracilis is limited to the Ladinian-Carnian (Senowbari-Daryan 2013). Ladinella porata occurs only until the end of the Carnian (Bernecker 2005). Thus, it is a good biostratigraphic marker for Upper Triassic reefs.

The presence of some Ladinian-Carnian biostratigraphic markers in reef limestone blocks of the SAC in Shikoku, and the comparison with other well-known reef fauna assemblages (see below) points to an age at least as old as the Lower Carnian and possibly even older. Therefore, a Ladinian? to Carnian age is proposed here for the described reef ecosystems of the SAC in Shikoku. This confirms an 
Table 1 Distribution of the taxa described in the text

\begin{tabular}{|c|c|c|c|c|}
\hline Taxa & Loc. 1 Tsuno & $\begin{array}{l}\text { Loc. } 2 \mathrm{Mt} \text {. } \\
\text { Sambosan }\end{array}$ & $\begin{array}{l}\text { Loc. } 3 \mathrm{Mt} \text {. } \\
\text { Ishidate }\end{array}$ & $\begin{array}{l}\text { Loc. } 4 \text { Konose } \\
\text { Kyo }\end{array}$ \\
\hline \multicolumn{5}{|l|}{ Scleractinian corals } \\
\hline Retiophyllia sp. & $\times$ & - & - & - \\
\hline Scleractinia sp. 1 & $\times$ & - & - & - \\
\hline Thamnasteriamorpha okudai & $x$ & - & - & - \\
\hline \multicolumn{5}{|l|}{ Sponges } \\
\hline Celyphia? minima & - & $x$ & $x$ & - \\
\hline Celyphia zoldana & $x$ & - & - & - \\
\hline Cryptocoelia zitteli & $\times$ & - & $x$ & - \\
\hline ?Murania kazmierczaki & $x$ & - & - & - \\
\hline ?Solenolmia sp. & - & - & - & $x$ \\
\hline Stylothalamia dehmi & - & $\times$ & - & - \\
\hline Uvanella irregularis & $x$ & $x$ & $?$ & $x$ \\
\hline Uvanella? lamellata & $x$ & - & - & - \\
\hline Zardinia perisulcata & $\times$ & - & - & $x$ \\
\hline \multicolumn{5}{|l|}{ Red algae (Solenoporacean) } \\
\hline Dendronella articulata & $x$ & - & - & - \\
\hline ?Parachaetetes cf. C. cassianus & $\times$ & $?$ & - & - \\
\hline \multicolumn{5}{|l|}{ Cyanophycean calcimicrobe } \\
\hline Girvanella sp. & $\times$ & $x$ & - & - \\
\hline \multicolumn{5}{|l|}{ Foraminifers } \\
\hline Ammobaculites/Reophax sp. & $\times$ & $?$ & - & - \\
\hline Arenovidalina chialingchiangensis & $\times$ & - & - & - \\
\hline Cucurbita infundibuliforme & $\times$ & $\times$ & - & $\times$ \\
\hline Hydrania dulloi & - & - & $x$ & $x$ \\
\hline ?Koskinobullina socialis & $\times$ & - & - & - \\
\hline Paleolituonella meridionalis & $\times$ & $\times$ & - & - \\
\hline Piallina bronnimanni & $\times$ & $?$ & - & $?$ \\
\hline Piallina tethydis & $\times$ & - & - & - \\
\hline Trocholina cordevolica & - & - & - & $x$ \\
\hline \multicolumn{5}{|l|}{ Microproblematica } \\
\hline Baccanella floriformis & $x$ & $x$ & - & $x$ \\
\hline ?Isnella misiki & $\times$ & $x$ & $?$ & $?$ \\
\hline Ladinella porata & $\times$ & - & $x$ & - \\
\hline Plexoramea cerebriformis & $x$ & $x$ & $?$ & $x$ \\
\hline Plexoramea gracilis & - & $x$ & $x$ & $x$ \\
\hline Radiomura cautica & $x$ & $x$ & $x$ & $x$ \\
\hline Tubiphytes spp. & $x$ & $\times$ & $x$ & $x$ \\
\hline \multicolumn{5}{|l|}{ Brachiopods } \\
\hline Gosaukammerella eomesozoica & $x$ & $x$ & - & - \\
\hline Thecideid brachiopods & $x$ & $x$ & - & - \\
\hline \multicolumn{5}{|l|}{ Polychaetes } \\
\hline Terebella sp. & $x$ & $x$ & - & $?$ \\
\hline Serpulids & $x$ & $?$ & $x$ & $?$ \\
\hline
\end{tabular}

early Late Triassic reef development on the top of these oceanic seamounts of Panthalassan origin. To date, the oldest age of SAC reefs in Japan was Carnian (SenowbariDaryan et al. 2012).

\section{Comparisons}

As established in the last section, the biota of the reef limestone in Shikoku includes numerous Ladinian-Carnian taxa. 


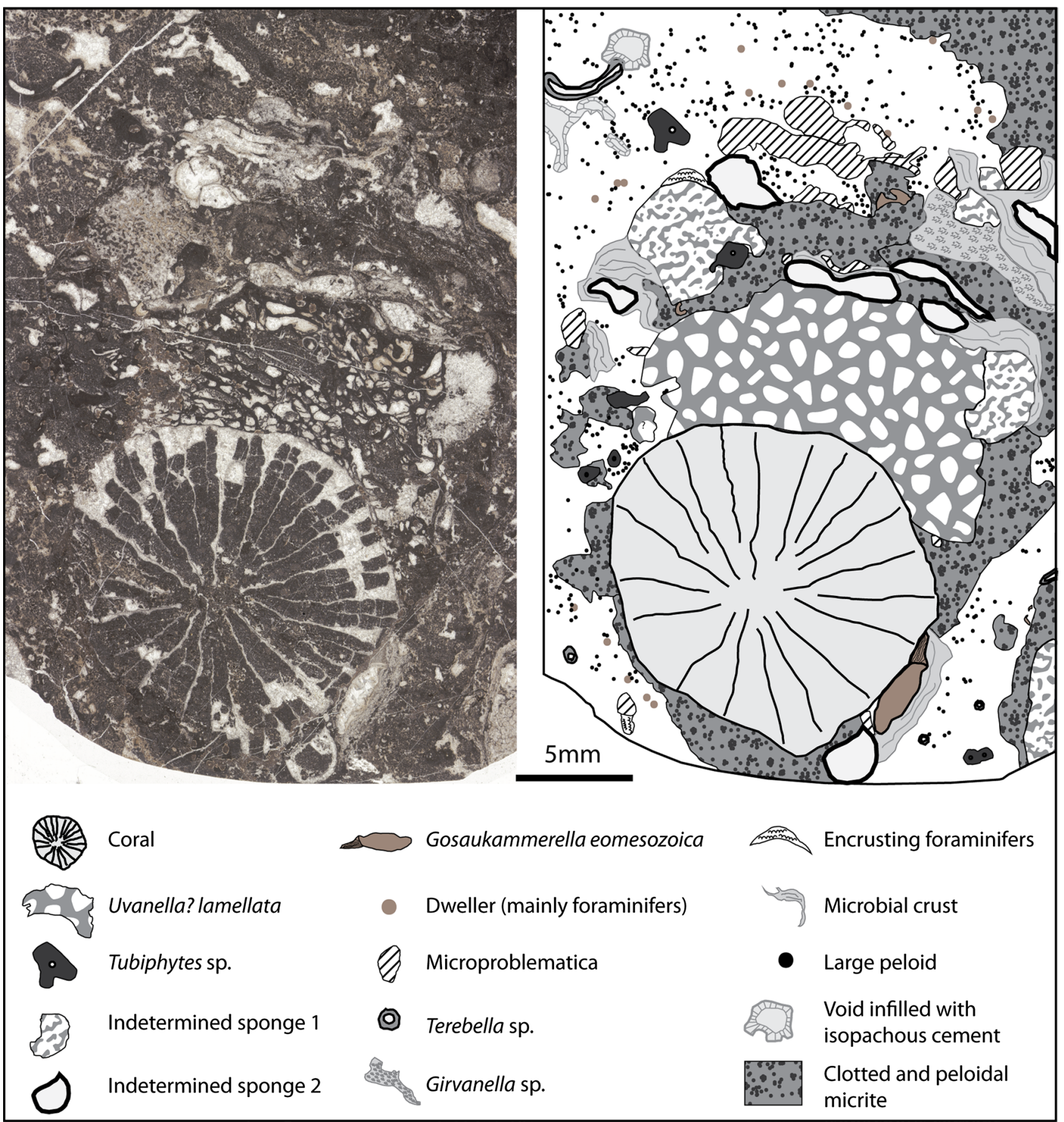

Fig. 8 Reef facies and sequence of encrustation. Coral-sponge-microproblematica boundstone and corresponding microfacies interpretation, showing numerous encrusters forming a thick and complex encrustation sequence CP127D

Moreover, the assemblage has a close affinity with Ladinian to Carnian reef assemblages of the Tethys realm, and particularly with the Carnian reefs of Oman and the Upper LadinianLower Carnian Cipit Boulders of the Dolomites (northern Italy). A comparison with these two coeval reef environments is detailed below.

\section{Carnian of Oman}

The Carnian limestones of Oman have been investigated by Bernecker (1996), Senowbari-Daryan et al. (1999), and Senowbari-Daryan and Bernecker (2009). The primary results are summarized in Bernecker (2005). A rich Carnian 
reef biota was described and the age diagnostic association includes the corals Volzeia badiotica, Rhopalodendron juliensis and Margarophyllia crenata, the sponges $C$. zitteli, Zardinia sp. and Uvanella irregularis, the serpulid Barbarafera carnica, the foraminifers Paraophtalmidium spp. and Cucurbita infundibuliforme, and the microproblematicum Ladinella porata. The material described in our study often displays associations that are similar to those identified in the Carnian of Oman (i.e., C. zitteli, Z. perisulcata, $U$. irregularis, and $C$. infundibuliforme frequently occur together).

\section{Upper Ladinian-Lower Carnian Cipit Boulders of the Dolomites}

The most striking similarities appear when comparing our material with the Cipit Boulders from the Cassian Formation of the Dolomites (northern Italy). The Cipit Boulders have been the subject of many paleontological studies since the 19th century (e.g., Richtofen 1860; Sánchez-Beristain 2010; Tosti et al. 2014). Many sponge taxa such as Zardinia perisulcata have been introduced from this area (Dieci et al. 1968). More recently Sánchez-Beristain (2010) and Sánchez-Beristain and Reitner (2012) performed an extensive study of the biota of the Cipit Boulders and discussed the ecology of that reef environment. They described several reef fauna associations, including corals (Margarosmilia, Retiophyllia), sponges (Precorynella, Murania), encrusting brachiopods, solenoporacean algae, Girvanella, Koskinobullina socialis, along with microbialitic crusts and thrombolytic structures. They also reported Lamelliconus cordevolicus (= Trocholina cordevolica). That assemblage bears striking similarities to the samples from Loc. 1 Tsuno, especially regarding the numerous sessile organisms and microbial crusts that formed a complex encrusting sequence upon the primary framebuilders.

\section{Preservation of the reef limestone}

Regarding the lithology of the Ladinian?-Carnian reef limestone of the SAC, we observed that the clasts that are enclosed in the breccia with a volcaniclastic matrix (VCM breccia) are overall better preserved than the nearby limestone slabs. In a similar way, the outstandingly preserved Cipit Boulders are also set in volcaniclastic sediments (e.g., Russo et al. 1997; Tosti et al. 2014). Accordingly, this mode of occurrence would explain the excellent preservation of the limestone, meaning that the circulation of diagenetic fluids was more difficult in volcaniclastic sediments, which prevented the recrystallization (Scherer 1977; Brachert and Dullo 1994; Russo et al. 1991). These repeated observations in different regions highlight the potential for an enhanced preservation of the reef limestone clasts when associated with volcaniclastic sediments.

\section{Reef ecology}

In reef ecosystems, sessile organisms and microbial crusts (secondary framebuilders) form encrustation sequences upon primary framebuilders (e.g., phaceloid corals, larger sphinctozoan and red algae). In our material, two types of encrustations have been observed. The first corresponds to thick encrustations (up to $1 \mathrm{~cm}$ ), which are mainly on corals, and the second consists of thin encrustations (10$100 \mu \mathrm{m})$ on other framebuilders such as sponges, solenoporacean algae and Tubiphytes. The thick encrustation sequences include various organisms such as Uvanella? lamellata, Gosaukammerella eomesozoica, ?Koskinobullina socialis, ?Murania kazmierczaki, Radiomura cautica, Girvanella sp., undetermined sponges, microproblematica and microbial crusts (Fig. 8). The smaller encrustations usually comprise Uvanella irregularis, Celyphia spp. and microbial crusts. The thick and complex sequences of encrustations would reflect the reef ecological succession, but among the investigated samples no specific pattern of encrustation sequences has been identified.

\section{Regional correlation and reef evolution in the SAC}

Carnian reefs biota have been described from several other localities in the SAC (Fig. 9). Especially interesting are the reef limestone clasts from the locality of Koguchi in Kyushu that show strong similarities in biotic content with our material (Kanmera 1964; Senowbari-Daryan et al. 2012). More precisely, taxa that occur both in Shikoku and at Koguchi locality are: corals Retiophyllia spp., Thamnasteriamorpha okudai, algae Parachaetetes cf. P. cassianus, foraminifers Cucurbita infundibuliforme, Hydrania dulloi, Paleolituonella meridionalis, microproblematica Ladinella porata, Plexoramea gracilis, Radiomura cautica and potentially the sponge Solenolmia. Additionally, Carnian corals, including Thamnasteriamorpha okudai, have been reported from the Daifugendake area on the Kii Peninsula, Honshu (Yamato Omine Research Group 1976; Okuda and Yamagiwa 1978; Okuda 2006; Stanley and Onoue 2015). Interestingly, the Carnian reef limestone that crops out in these two localities occurs also as limestone clasts that are embedded in a volcaniclastic matrix (VCM breccia). This observation corroborates the interpretation that the different Carnian limestone units of the SAC experienced a similar geological history despite their current wide distribution along this tectonic belt (approximately $550 \mathrm{~km}$ from the Koguchi locality in the southwest to the Daifugendake area in the northeast). It follows that these coeval limestone units, which are characterized by the same biota, originated 
Fig. 9 Stratigraphic framework of the Sambosan limestone. Stratigraphic ranges are from Onoue and Sano (2007) [1]; Onoue and Stanley (2008) [2]; Chablais et al. (2010c) [3]; Chablais et al. (2011) [4]; Senowbari-Daryan et al. (2012) [5] and this study. Chronostratigraphy after the International Commission on Stratigraphy 2015

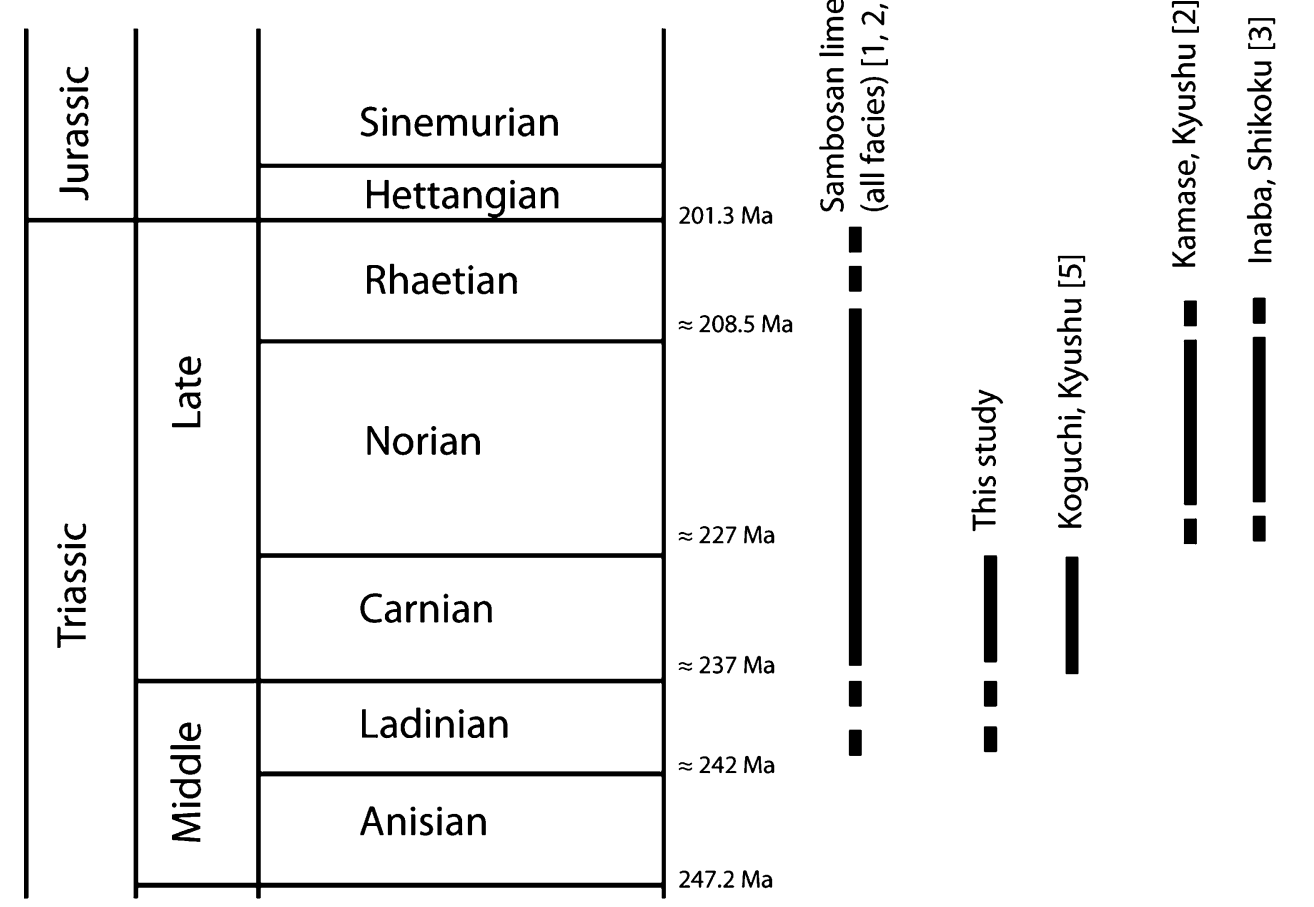

at least from the same area of Panthalassa, if not from the same seamount.

The present study documents widespread Ladinian?Carnian reef limestone and extends the stratigraphic range of reefs in the SAC. The reefs reported in this work likely represent the initiation of the carbonate platforms at the tops of Panthalassa seamounts. Consequently, Norian reefs that have been previously described in the SAC (Kamase reef, Onoue and Stanley 2008; Inaba reef, Chablais et al. 2010c) represent a later stage in the Upper Triassic reef evolution of the Panthalassa build-ups.

\section{Paleobiogeography}

The geographic distribution of the taxa described in the previous sections confirms a strong biogeographical affinity of the Ladinian?-Carnian reef biota of the SAC with those of the Tethyan domain. This Tethyan affinity has already been observed for bivalves (Tamura 1990, 1992; Onoue and Tanaka 2002, 2005), foraminifers (Kristan-Tollmann 1991; Chablais et al. 2011), sponges and microproblematica (Senowbari-Daryan et al. 2012) and microcoprolites (SenowbariDaryan et al. 2010), both for Carnian and Norian-Rhaetian ages. More precisely, Chablais et al. (2011) proposed a stronger affinity with the Southern margin of the Tethys on the basis of semi quantitative analysis of foraminifer diversity, and that interpretation is consistent with results of the present paper. Accordingly, we can state that the Upper
Triassic reef biota of the Tethys and western Panthalassa are rather similar and mainly include cosmopolitan taxa. However, concerning coral fauna of the SAC, Stanley and Onoue (2015) mentioned some affinities with the Tethys but also reported six endemic taxa among the ten that were presented in their study, which suggest a biogeographical isolation. Nevertheless, based on the literature and our results, significant endemism is not evident for other taxonomic groups.

\section{Conclusions}

Our study of the reef limestone clasts of the Sambosan Accretionary Complex in several localities of Shikoku Island (Japan), led us to:

- Report reef biota, including seventeen species described for the first time in Japan, such as the calcareous sponges Zardinia perisulcata, C. zitteli, Celyphia zoldana, Celyphia? minima, Stylothalamia dehmi, Uvanella? lamellata, ?Murania kazmierczaki; solenoporacean red algae Dendronella articulata; foraminifers Arenovidalina chialingchiangiensis, Trocholina cordevolica, ?Koskinobullina socialis, Piallina bronnimanni, Piallina tethydis and nubeculariid foraminifers; brachiopod Gosaukammerella eomesozoica and the microproblematicum Plexoramea cerebriformis. This supports a high biodiversity of Carnian reefs in Panthalassa. 
- Propose a Ladinian?-Carnian age for this reef limestone based on biostratigraphic markers and biotic assemblages and to discriminate within the SAC between Ladinian-Carnian and Norian reefs at a regional scale.

- Support the close biogeographical affinity of the SAC with the Tethyan realm despite difficulties in the comparison with poorly documented eastern Panthalassa, Ladinian-Carnian reef fauna.

- Provide new and valuable data for paleobiogeography and paleobiodiversity studies that will inform global databases such as the PaleoReefs database or the Paleobiology database. This is particularly relevant because little is known about Carnian reef biota of the Panthalassa realm.

Acknowledgments This contribution is part of the REEFCADE projects (Swiss National Science Foundation \#200020-156422 and 200020-137661). We thank Professor Tetsuji Onoue and Daisuke Yamashita for their help in the field and discussion about the SAC. Roberto Rettori, Sylvain Rigaud, Michaela Bernecker, Bernard Lathuillière, Elias Samankassou, and Ewa Ronieviwcz are thanked for the useful discussions and help concerning the micropaleontological determinations. Baba Senowbari-Daryan and an anonymous reviewer are thanked for their valuable comments.

\section{References}

Barattolo F, Mastandrea A, Russo F (1993) Redescription of the Carnian Dendronella articulata Moussavian \& Senowbari-Daryan 1988 (Rhodophyceae). In: Studies on fossil benthic algae: proceedings of the 5th international symposium on fossil algae, Capri, 7-12 April, 1991. Mucchi, p 47

Bernecker M (1996) Upper Triassic reefs of the Oman Mountains: data from the South Tethyan margin. Facies 34:41-76

Bernecker M (2005) Late Triassic reefs from the Northwest and South Tethys: distribution, setting, and biotic composition. Facies 51:442-453

Bole B (2002) Karbonatne kamnine Pece. Geologija 45:59-69

Boni M, Iannace A, Torre M, Zamparelli V (1994) The Ladinian-Carnian reef facies of Monte Caramolo (Calabria, southern Italy). Facies 30:101-117

Borza K, Samuel O (1978) Pseudocucurbita nov. gen. (incertae sedis) from the Upper Triassic of the West Carpathians (Czechoslovakia). Geol Zborn Solov Akad Vied 29:67-75

Brachert T, Dullo WC (1994) Micrite crusts on Ladinian foreslopes of the Dolomites seen in the light of a modern scenario from the Red Sea. Abh Geol Bundestalt 50:57-68

Brandner R, Flügel E, Senowbari-Daryan B (1991) Microfacies of carbonate slope boulders: indicator of the source area (Middle Triassic: Mahlknecht Cliff, Western Dolomites). Facies 25:279-295

Buser S, Ramovš A, Turnšek D (1982) Triassic reefs in Slovenia. Facies 6:15-23

Carrillat A, Martini R (2009) Palaeoenvironmental reconstruction of the Mufara Formation (Upper Triassic, Sicily): high-resolution sedimentology, biostratigraphy and sea-level changes. Palaeogeogr Palaeoclimatol Palaeoecol 283:60-76

Chablais J (2010) Sedimentology and Biostratigraphy of the Upper Triassic Atoll-type Carbonates of the Sambosan Accretionary Complex (Panthalassan Domain, Japan): depositional Setting,
Paleobiogeography and Relationship to their Counterparts in the Tethys. University of Geneva, Geneva

Chablais J, Martini R, Onoue T (2010a) Aulotortus friedli from the Upper Triassic gravitational flow deposits of the Kumagawa River (Kyushu, southwest Japan). Paleontol Res 14:151-160

Chablais J, Martini R, Samankassou E et al (2010b) Microfacies and depositional setting of the Upper Triassic mid-oceanic atolltype carbonates of the Sambosan Accretionary Complex (southern Kyushu, Japan). Facies 56:249-278

Chablais J, Onoue T, Martini R (2010c) Upper Triassic reef-limestone blocks of southwestern Japan: new data from a Panthalassan seamount. Palaeogeogr Palaeoclimatol Palaeoecol 293:206-222

Chablais J, Martini R, Kobayashi F et al (2011) Upper Triassic foraminifers from Panthalassan carbonate buildups of Southwestern Japan and their paleobiogeographic implications. Micropaleontology 57:93-124

Chafetz HS (1986) Marine peloids: a product of bacterially induced precipitation of calcite. J Sediment Res 56:812-817

Della Porta G, Kenter JAM, Bahamonde JR (2002) Microfacies and paleoenvironment of Donezella accumulations across an upper Carboniferous high-rising carbonate platform (Austurias, NW Spain). Facies 46:149-168

Di Bari D, Laghi GF (1994) Involutinidae Bütschli (Foraminiferida) in the Carnian of the northeastern Dolomites (Italy). Mem Sci Geol 46:93-118

Dieci G, Antonacci A, Zardini R (1968) Le spugne cassiane (Trias medio-superiore) della regione dolomitica attorno a Cortina d'Ampezzo. Bolletino della Soc Paleontol Ital 7:94-155

Dullo W-C, Lein R (1982) Facies and environment of the Leckkogel beds (Carnian; Alps). Facies 6:25-35

Dullo W-C, Flügel E, Lein R et al (1987) Algen, Kalkschwämme und Mikroproblematika aus unterkarnischen Riffkalken des Bosruck-Gipfels (Nördliche Kalkalpen, Österreich). Jb Geol B-A 129:4

Dupraz C (1999) Paléontologie, paléoécologie et évolution des faciès récifaux de l'Oxfordien Moyen-Supérieur (Jura suisse et français). University of Fribourg

Dupraz C, Strasser A (1999) Microbialites and micro-encrusters in shallow coral bioherms (Middle to Late Oxfordian, Swiss Jura Mountains). Facies 40:101-129

Emmerich A, Zamparelli V, Bechstädt T, Zühlke R (2005) The reefal margin and slope of a Middle Triassic carbonate platform: the Latemar (Dolomites, Italy). Facies 50:573-614

Endo R, Horiguchi M (1967) Calcareous Algae from the Konose Group in Kyushu, I. Bull Tokyo Coll Domest Sci 7:1-12

Finks RM, Rigby JK (2004) Hypercalcified sponges. Treatise Invertebr. Paleontol. pt. E, Porifera. pp 585-758

Flügel E (1986) Zur Mikrofazies oberanisischer Riffkalke in den östlichen Nordkarawanken, Kärnten. Carinthia II 176:463-478

Flügel E (2002) Triassic reef patterns. In: Kiessling Wolfgang, Flügel E, Golonka J (eds) Phaneroz. reef patterns. Special Publications of SEPM, pp 391-463

Flügel E, Velledits F, Senowbari-Daryan B, Riedel P (1992) Rifforganismen aus "Wettersteinkalken"(Karn?) des Bükk-Gebirges, Ungarn. Geol Paläont Mitt Innsbruck 18:35-62

Fois E (1981) The Sass da Putia carbonate buildup (Western Dolomites): biofacies succession and margin development during the Ladinian. Riv Ital di Paleontol e Stratigr 87:565-598

Fontaine H, Khoo HP, Vachard D (1988) Discovery of Triassic fossils at Bukit Chuping, in Gunung Sinyum area, and at Kota Jin, Peninsular Malaysia. J Southeast Asian Earth Sci 2:145-162

Fürsich FT, Werner W (1991) Palaeoecology of coralline sponge-coral meadows from the Upper Jurassic of Portugal. Paläontologische Zeitschrift 65:35-69

Gale L, Rettori R, Martini R (2012) Critical review of Pseudocucurbitidae (Miliolina, Foraminiferea) from the Late 
Triassic reef environments of the Tethyan area. J Micropalaeontol 31:179-186

Ho Y (1959) Triassic foraminifera from the Chialingkiang Limestone of south Szechuan. Acta Palaeontol Sin 7:387-418

Ishida K (1983) Stratigraphy and radiolarian assemblages of the Triassic and Jurassic siliceous sedimentary rocks in Kōnose Valley, Tokushima Prefecture, southwest Japan. J Sci Coll Gen Educ Univ Tokushima 16:111-141

Ishida K (1987) Geology and microbiostratigraphy of the Southern Chichibu Terrane in eastern Shikoku, Southwest Japan. J Sci Coll Gen Educ Univ Tokushima 20:47-121

Jablonsky E (1971) Segmentierte Kalkschwamme-Sphinctozoa der Westkarpaten (von der Lokalitat Liptovska Osada).-GeoL zborn. Geol Carpathica 22:2-333

Kanmera K (1964) Triassic coral faunas from the Konosé Group in Kyushu. Mem Fac Sci Kyushu Univ Ser D 15:117-147

Kanmera K (1969) Litho-and bio-facies of Permo-Triassic geosynclinal limestone of the Sambosan Belt in southern Kyushu. Spec Publ Palaeontol Soc Jpn 14:13-39

Kiessling W, Flügel E (2000) Late Paleozoic and Late Triassic limestones from North Palawan block (Philippines): microfacies and paleogeographical implications. Facies 43:39-77

Kobayashi T (1931) Notes on a new occurrence of Ladino-Carnic limestone at Sambosan, Tosa Province, Japan. Jpn J Geol Geogr 8:251-258

Kobayashi F, Martini R, Rettori R et al (2006) Triassic foraminifers of the Lampang Group (northern Thailand). J Asian Earth Sci 27:312-325

Korngreen D, Benjamini C (2006) Foraminiferal assemblage-based biostratigraphy and correlation of the Triassic of northern Israel. Isr J Earth Sci 55:209-235

Kristan-Tollmann E (1991) Triassic Tethyan microfauna in Dachstein limestone blocks in Japan. Int Symp Shallow Tethys 3:35-49

Loeblich AR, Tappan H (1988) Foraminiferal genera and their classification. Van Nostrand Reinhold, New York

Martindale RC, Zonneveld J-P, Bottjer DJ (2010) Microbial framework in Upper Triassic (Carnian) patch reefs from Williston Lake, British Columbia, Canada. Palaeogeogr Palaeoclimatol Palaeoecol 297:609-620

Martindale RC, Corsetti FA, Bottjer DJ, Senowbari-Daryan B (2012) Microbialite fabrics and diminutive skeletal bioconstructors in Lower Norian Summit Point reefs, Oregon, United States. Palaios 27:489-508

Martindale RC, Krystyn L, Bottjer DJ et al (2013) Depth transect of an Upper Triassic (Rhaetian) reef from Gosau, Austria: microfacies and community ecology. Palaeogeogr Palaeoclimatol Palaeoecol 376:1-21

Martini R, Rettori R, Urosevic D, Zaninetti L (1995) Le genre Piallina Rettori et Zaninetti (foraminifere) dans des calcaires a turriglomines du Trias (Carnien) de Serbie orientale (domaine Carpatho-Balkanique). Rev Paléobiol 14:411-415

Mori R (1983) A study of the calcareous algae from the Konosé Group in Kyushu. Bull Tokyo Coll Domest Sci 23:33-39

Moussavian E, Senowbari-Daryan B (1988) Dendronella articulata n. gen., n. sp.: a New Calcareous Alga from the Cassian Formation (Upper Triassic/Carnian; Southern Alps). Facies 19:251-258

Moussavian E, Vecsei A (1995) Paleocene reef sediments from the maiella carbonate platform, Italy. Facies 32:213-221

Müller-Wille S, Reitner J (1993) Palaeobiological reconstructions of selected spinctozoan sponges from the Cassian Beds (Lower Carnian) of the Dolomites (northern Italy). Berliner Geowissenschaftliche Abhandlungen 9:253-281

Okuda H (2006) The mode of limestones and the age of scleractinian corals from limestone blocks: reexamination of corals from the Wasabidani complex in the central area of the Kii Mountains, southwest Japan. Earth Sci 60:389-401
Okuda H, Yamagiwa N (1978) Triassic corals from Mt. Daifugen, Nara Prefecture southwest Japan. Trans Proc Palaeont Soc Japan NS 110:297-305

Okuda H, Ezaki Y, Yao A (2005) Geological complexes of Sanbosan area and limestones containing Triassic scleractinian corals in Kochi Prefecture, southwestern Japan. Earth Sci 59:371-382

Olivier N, Carpentier C, Martin-Garin B et al (2004) Coral-microbialite reefs in pure carbonate versus mixed carbonate-siliciclastic depositional environments: the example of the Pagny-surMeuse section (Upper Jurassic, northeastern France). Facies $50: 229-255$

Onoue T, Sano H (2007) Triassic mid-oceanic sedimentation in Panthalassa Ocean: Sambosan Accretionary Complex, Japan. Isl Arc 16:173-190

Onoue T, Stanley GD (2008) Sedimentary facies from Upper Triassic reefal limestone of the Sambosan Accretionary Complex in Japan: mid-ocean patch reef development in the Panthalassa Ocean. Facies 54:529-547

Onoue T, Tanaka H (2002) Discovery of Upper Triassic bivalves from Sambosan Subterrane, Itsuki mura area, Kumamoto Prefecture, and its geologic implication. J Geol Soc Jpn 108:610-613

Onoue T, Tanaka H (2005) Late Triassic bivalves from Sambosan Accretionary Complex, southwest Japan, and their biogeographic implications. Paleontol Res 9:15-25

Onoue T, Nagai K, Kamishima A et al (2004) Origin of basalts from Sambosan Accretionary Complex, Shikoku and Kyushu. J Geol Soc Japan 110:222-236

Ott E (1967) Segmentierte Kalkschwamme (Sphinctozoa) aus der alpinen Mitteltrias und ihre Bedeutung als Riffbildner im Wettersteinkalk. Bayer. Akad. der Wissenschaften. Math. Klasse. Abhandlungen, n.F. 131:

Pantic S (1971) Baccanella floriformis n. gen. n. sp. from the Middle Triassic of the Dinarids. Ann Géol Pénins Balk 36:105-111

Payne JL, Summers M, Rego BL et al (2011) Early and Middle Triassic trends in diversity, evenness, and size of foraminifers on a carbonate platform in south China: implications for tempo and mode of biotic recovery from the end-Permian mass extinction. Paleobiology 37:409-425

Pérez-López A, Márquez L, Pérez-Valera F (2005) A foraminiferal assemblage as a bioevent marker of the main Ladinian transgressive stage in the Betic Cordillera, southern Spain. Palaeogeogr Palaeoclimatol Palaeoecol 224:217-231

Pleş G, Mircescu CV, Bucur II, Săsăran E (2013) Encrusting microorganisms and microbial structures in Upper Jurassic limestones from the Southern Carpathians (Romania). Facies 59:19-48

Pratt BR (1995) The origin, biota and evolution of deep-water mudmounds. In: Monty CLV, Bosence DWJ, Bridges PH, Pratt BR (eds) Carbonate mud-mounds. Their Orig. Evol. Publ. Intern. Assoc. Sedimentol, pp 49-123

Pratt BR (2001) Calcification of cyanobacterial filaments: Girvanella and the origin of lower Paleozoic lime mud. Geology 29:763-766

Reid RP (1987) Nonskeletal peloidal precipitates in Upper Triassic reefs, Yukon Territory (Canada). J Sediment Res 57:893-900

Rettori R, Zaninetti L, Martini R, Vachard D (1993) Piallina tethydis gen. et sp. nov. (Foraminiferida) from the Triassic (Carnian) of the Kocaeli Peninsula, Turkey. J Micropalaeontol 12:171-174

Riding R (1991) Calcified cyanobacteria. Calcareous algae and stromatolites. Springer, pp 55-87

Riding R, Guo L (1992) Affinity of tubiphytes. Palaeontology 35:37-49

Rigaud S, Blau J, Martini R, Rettori R (2013) Taxonomy and phylogeny of the Trocholinidae (Involutinina). J Foraminifer Res 43:317-339

Roniewicz E, Stanley Jr GD (1998) Middle Triassic cnidarians from the New Pass range, central Nevada. J Paleontol:246-256 
Rüffer T, Zamparelli V (1997) Facies and biota of Anisian to Carnian carbonate platforms in the Northern Calcareous Alps (Tyrol and Bavaria). Facies 37:115-136

Russo F, Neri C, Mastandrea A, Laghi G (1991) Depositional and diagenetic history of the Alpe di Specie (Seelandalpe) fauna (Carnian, Northeastern Dolomites). Facies 25:187-210

Russo F, Neri C, Mastandrea A, Baracca A (1997) The mud mound nature of the Cassian Platform Margins of the Dolomites. A case history: the Cipit boulders from Punta Grohmann (Sasso Piatto Massif, northern Italy). Facies 36:25-36

Sánchez-Beristain JF (2010) Paleoecological and geochemical studies on sponge-microencruster-bearing communities contained in selected Cipit Boulders from the St. Cassian Formation (Lower Carnian, Upper Triassic) of the Dolomites, northeastern Italy. Göttingen, Georg-August Universität, Diss., 2010

Sánchez-Beristain F, Reitner J (2012) Paleoecology of microencrusters and encrusting "coralline" sponges in Cipit boulders from the Cassian formation (upper Ladinian-lower Carnian, Dolomites, northern Italy). Paläontol Zeitschrift 86:113-133

Sánchez-Beristain F, López-Esquivel Kranksith L, García-Barrera P, Reitner J (2013) El primer registro de Koskinobullina sociales (Foraminífera) para el Triásico de Europa y sus implicaciones paleoecológicas. Boletín Geol Min 124:437-450

Sano H, Kanmera K (1996) Microbial controls on Panthalassan Carboniferous-Permian oceanic buildups, Japan. Facies 34:239-255

Scherer M (1977) Preservation, alteration and multiple cementation of aragonitic skeletons from the Cassian beds U. Triassic, Southern Alps: petrographic and geochemical evidences. Neues Jahrb für Geol und Paläontologie Abhandlungen 154:213-262

Schlagintweit F (2004) Murania reitneri n. sp., a new sclerosponge from the Upper Jurassic of the Northern Calcareous Alps (Plassen Formation, Austria and Germany). Austr J Earth Sci 95:37-45

Schlagintweit F, Gawlick H (2009) Enigmatic tubes associated with microbial crusts from the Late Jurassic of the Northern Calcareous Alps (Austria): a mutualistic sponge-epibiont consortium? Lethaia 42:452-461

Senowbari-Daryan B (1981) Zur Paläontologie des Riffes innerhalb der Amphyclinen-Schichten bei Hudajužna, Slowenien: paleontološka obdelava grebena med amfiklinskimi skladi pri Hudajužni. Razpr 4. Razreda SAZU 23:99-118

Senowbari-Daryan B (1983) Zur Gattung Pseudocucurbita Borza and Samuel, 1978 (= pro Cucurbita Jablonský, 1973) und Beschreibung vergleichbarer problematischer Organismen aus der Obertrias des alpin-mediterranen Raumes. Riv Ital Paleont $88: 181-250$

Senowbari-Daryan B (1984) Mikroproblematika aus den obertriadischen Riffkalken von Sizilien. Münster Forsch Geol Paläont 61:1-81

Senowbari-Daryan B (2007) Isnella misiki nov. gen., nov. sp., kein Tubiphytes aber eine mögliche Foraminifere, Wurmröhre oder Cyanophycee aus den ladinisch-karnischen Riffkalken der Tethys. J Alp Geol (Mitt Ges Geol Bergbaustud Österr) 48:45-56

Senowbari-Daryan B (2013) Tubiphytes Maslov, 1956 and description of similar organisms from Triassic reefs of the Tethys. Facies 59:75-112

Senowbari-Daryan B, Bernecker M (2009) Carnian (Upper Triassic) reef biota from limestone blocks of different tectonic settings in Oman. Beringeria 40:3-53

Senowbari-Daryan B, Flügel E (1993) Tubiphytes Maslov, an enigmatic fossil: classification, fossil record and significance through time: Part I. Discussion of Late Paleozoic material. Stud Foss Benthic Algae Soc Palaeontol Ital Bolletino, Spec $1: 353-382$
Senowbari-Daryan B, Flügel E (1996) A "Problematic fossil" revealed: pycnoporidium ? eomesozoicum Flügel, 1972 (Late Triassic, Tethys) — not an enigmatic alga but a strophomenid brachiopod (Gosaukammerella n.g.). Facies 34:83-99

Senowbari-Daryan B, García-Bellido DC (2002) Fossil "Sphinctozoa": chambered sponges (polyphyletic). Syst. porifera. Springer, pp 1511-1538

Senowbari-Daryan B, Link M (2005) Solenoporaceen aus den obertriassischen (Nor) Riffkalken des Taurusgebirges (Antalya-Gebiet, Südtürkei). Paläontologische Zeitschrift 79:409-427

Senowbari-Daryan B, Rigby JK (2015) Sphinctozoan and Inozoan Hypercalcified Porifera: an overview. Treatise Invertebr. Paleontol. (Porifera, revised), pp 321-395

Senowbari-Daryan B, Schäfer P (1983) Zur Sphinctozoen-Fauna der obertriadischen Riffkalke ("Pantokratorkalke") von Hydra, Griechenland. Geol Palaeontol 17:179-205

Senowbari-Daryan B, Zühlke R, Bechstädt T, Flügel E (1993) Anisian (Middle Triassic) buildups of the Northern Dolomites (Italy): the recovery of reef communities after the Permian/Triassic crisis. Facies 28:181-256

Senowbari-Daryan B, Bernecker M, Krystyn L, Siblik M (1999) Carnian reef biota from a megabreccia of the Hawasina complex (Al Aqil, Oman). Riv Ital Di Paleontol E Stratigr 105:327-342

Senowbari-Daryan B, Link M, Isintek I (2006) Calcareous algae from the Triassic (Anisian reef boulders and Norian reef limestones) of Karaburun, western Turkey. Facies 52:129-148

Senowbari-Daryan B, Bucur II, Schlagintweit F et al (2008) Crescentiella, a new name for "Tubiphytes" morronensis CRESCENTI, 1969: an enigmatic Jurassic-Cretaceous microfossil. Geol Croat 61:185-214

Senowbari-Daryan B, Chablais J, Martini R (2010) New Crustacean Microcoprolites of the Upper Triassic Limestones of the Sambosan Accretionary Complex, Japan. J Paleontol 84:98-108

Senowbari-Daryan B, Stanley GD Jr, Onoue T (2012) Upper Triassic (Carnian) reef biota from the Sambosan Accretionary Complex, Kyushu, Japan. Facies 58:671-684

Stanley GD Jr, Onoue T (2015) Upper Triassic reef corals from the Sambosan Accretionary Complex, Kyushu, Japan. Facies 61:1-27

Tamura M (1990) The distribution of Japanese Triassic bivalve faunas with special reference to parallel distribution of inner ArctoPacific fauna and outer Tethyan fauna in Upper Triassic. PreCretaceous Terranes of Japan 347-359

Tamura M (1992) Difference between the Kochigatani and Tethyan bivalve faunas in the Late Triassic of Japan and its implication. J Geol Soc Japan 98:979-989

Tosti F, Mastandrea A, Guido A et al (2014) Biogeochemical and redox record of mid-late Triassic reef evolution in the Italian Dolomites. Palaeogeogr Palaeoclimatol Palaeoecol 399:52-66

Trifonova E (1993) Taxonomy of Bulgarian Triassic foraminifera. II. Fam Endothyridae to Ophthalmidiidae Geol Balc 23:19-66

Velledits F, Pero C, Blau J, Senowbari-Daryan B (2011) The oldest Triassic platform margin reef from the alpine Carpathian region (Aggtelek, NE Hungary): platform evolution, reefal biota and biostratigraphic framework. Riv Ital di Paleontol e Stratigr 117:221-268

Richthofen F von (1860) Geognostische Beschreibung der Umgebung von Predazzo, St. Cassian und der Seiser Alpe Südtirol

Wolff H (1973) Fazies-Gliederung und Paläogeographie des Ladins in den bayerischen Kalkalpen zwischen Wendelstein und Kampenwand. Neues Jahrb für Geol und Paläontologie Abhandlungen 143:246-274

Wurm D (1982) Mikrofazies, Paläontologie und Palökologie der Dachsteinriffkalke (Nor) des Gosaukammes, Österreich. Facies 6:203-295 
Yamato Omine Research Group (1976) Paleozoic and Mesozoic systems in the central area of the Kii mountains, Southwest Japan (Part 1). Earth Sci 30:259-267

Yamato Omine Research Group (1981) Paleozoic and Mesozoic Systems in the Central Area of the Kii Mountains, Southwest Japan Appendix 2 Mesozoic of the Sambosan Area in the Central Shikoku, Southwest Japan. Guid. B. Excursion Prep. 35th Annu. Meet. Assoc. Geol. Collab. Japan. pp 68-88

Zaninetti L (1976) Les foraminifères du Trias: essai de synthèse et corrélation entre les domaines mésogéens européen et asiatique. Rivista italiana di paleontologia e stratigrafia
Zaninetti L (1977) Sur quelques synonymes du genre Galeanella Kristan, 1958, un Foraminifere de la Téthys triasique. Note Lab Paléont Univ Genève 2:1-3

Zonneveld J-P, Henderson CM, Stanley GD Jr et al (2007) Oldest scleractinian coral reefs on the North American craton: Upper Triassic (Carnian), northeastern British Columbia, Canada. Palaeogeogr Palaeoclimatol Palaeoecol 243:421-450 